\title{
Janusz Małłek \\ THE HISTORY OF THE LANDTAG OF THE DUCHY OF PRUSSIA IN 1566
}

Słowa kluczowe: $\quad$ Pruski sejm krajowy, Prusy książęce, Albrecht, książę Albrecht Fryderyk, stany pruskie

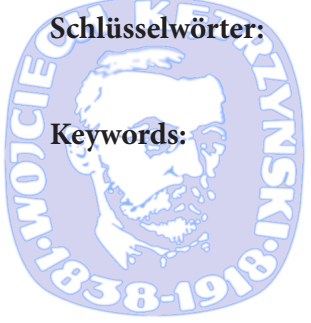

Preußischen Landtag, Herzogtum Preußen, Herzog Allbrecht, Herzog Albrecht Friedrich, Preußischer Landtag

Prussian Landtag, Duchy of Prussia, Albrecht duke of Prussia, Albert

Frederic Duke of Prussia, Prussian estates

\section{Introductory remarks}

In 1960, at Nicolaus Copernicus University in Toruń, I defended my Master's thesis entitled "Dzieje sejmu Prus Książęcych w roku 1566" (The History of the Landtag of the Duchy of Prussia in 1566) written under the supervision of Prof. Karol Górski. A year later, I published in "Komunikaty Mazursko-Warmińskie" an extended and improved chapter III of this work devoted to the genesis of the Prussian Landtag we are interested in ${ }^{1}$. The next stage was originally to announce the publication of the following chapter of this work concerning the very course of the Landtag debates. This did not happen. It seemed to me then that a more urgent task would be to write an article about the criminal trial of the new Dukely advisors at the Landtag. Such a study appeared in print as early as 1963 also in the "Komunikaty Mazursko-Warmińskie". The proceedings of the Lantag in the Duchy of Prussia in 1566 were different from those of the previous Landtag in Prussia. The royal commissioners, whose task was to alleviate a conflict that arose

1 J. Małłek, Geneza sejmu 1566 r. w Prusach Książęcych, Komunikaty Mazursko-Warmińskie, nr. 4(74), 1961, pp. 497-527; re-publication: idem, Od Prus do Mazur. Szkice z dziejów Prus, Pomorza, Warmii i Mazur, Dąbrówno 2016, pp. 143-167.

2 J. Małłek, Proces kryminalny nowych radców w Knipawie-Królewcu (9.X-28.X.1566 r.), Komunikaty Mazursko-Warmińskie, nr 2(80), 1963, pp.181-232; re-publication, idem, Od Prus do Mazur, pp. 168-212. 
between Duke Albrecht and the Estates of the realm, took part in it ${ }^{3}$. The trace of their activity was a diary published by Adolf Pawiński ${ }^{4}$. He also provided the edition of the diary with an extensive introduction, which in fact is a monograph ${ }^{5}$ on the interventions of Polish commissioners in the functioning of the Prussian fief. It still retains its value, especially in the sphere of factography. It was published in German in the $18^{\text {th }}$ century. "Dzienniczek komisarzy"6 (Commissioners' Diary), which is a description of their activities, was published in German, but has not been completed. It was most probably written by the Prussian nobleman Frederick or Eliasz Kanitz. An unusual event in the practice of the Prussian Landtag during the reign of Duke Albrecht was also the aforementioned trial of the new advisers. Apart from these two extraordinarily functioning forms of the Landtag, i.e. the participation of royal commissioners and the criminal trial, the Landtag held its sessions in its traditional manner. The present text, written in 1960, is devoted to it and is now supplemented and amended.

The basic source - besides the ones already mentioned - for our topic is a compilation of texts taken from manuscripts, from the royal archive published in "Acta Borussica" in 1732". Inside we find a diary of the session of the Landtag and fragments of the text from the aforementioned "Dzienniczek komisarzy" and undoubtedly from the unpreserved acts of the trial. The state of research has not changed significantly over the past half-century. The discussion contained in my article "Proces kryminalny nowych radców w Knipawie-Królewcu" (Criminal trial of new counsels in Knipawa-Königsberg) is still valid'. They need only be supplemented by a book by Everhard K.B. Kleinertz ${ }^{9}$ about the history of the Duchy of Prussia in the late years of the reign of Duke Albrecht 1562-1568 and Jörg Rainer Fligge $^{10}$ about the relationship between Duke Albrecht and Osiandrism. Finally, some additions were made to the queries in the Provincial State Archive in Olsztyn $^{11}$, in the Central Archive of Historical Records in Warsaw ${ }^{12}$. The query in the former royal archive, in the departments of Herzogliches Briefarchiv and Ostpreus-

3 Estates of the realm were usually three orders of social hierachy, made up of clergy, noblemen, and commoners.

4 De rebus ac statu Ducatus Prussiae tempore Alberti senioris..., ed. A. Pawiński, Warszawa 1879 (further $-\mathrm{DR})$.

5 While quoting this monograph, otherwise than in the source edition, web pages are marked with Roman letters (further - Pawiński, DR).

6 Memorial was sich von der Königlichen Kommisarien Ankunft zugetragen, Preussische Todes Tempel, [ed. Schultz and Lilienthal], p. 1. 1728-1730 (further - Memorial, PTT).

Historie von Funck, Schnell, Horst und Steinbach, ex actis publicis mstcis - Acta Borussica, (further AB), v. III, Leipzig 1732

8 J. Małłek, Od Prus do Mazur, pp. 169-173.

9 E.B.K. Kleinertz, Die Politik der Lanstände im Herzogtum Preussen 1562-1568, Bonn 1971.

10 J.R. Fligge, Herzog Albrecht von Preussen und der Osiandismus 1522-1568, Bonn 1972.

11 State Archive in Olsztyn (further - APO), Preussische Landtagshandlungen, Sygn. V/3-6.

12 Central Archive of Historical Records in Warsaw, Crown Metric 102 (diary of commissioners). 
sische Folianten 492-494 at the time in Göttingen in 1966 and 1967, temporarily limited to a few weeks and focused on a different topic, did not in principle bring any additions. Also the detailed research of E.K.B. Kleinertz ${ }^{13}$ in this archive did not change the factography of the Prussian Parliament of 1566. It is the most complete description of the sources for the history of this Parliament in the collection of the royal archives ${ }^{14}$. In order to supplement genealogical information about the nobility of Dukely Prussia, especially the issue of collusion, it is also worth to refer to "Staemmata genealogica" by Johann Henneneberger in the edition of George J. Kleiser ${ }^{15}$. When using this edition, however, the information contained therein should be confronted with other sources and studies. For the purpose of this article this was not necessary and therefore this edition was not recorded in footnotes.

\section{The first period: From the beginning of the Landtag until the arrival of the Royal Commissioners (5 August 1566 - 23 August 1566) ${ }^{16}$}

The first period of the Landtag of 1566 is an initial phase in which the Estates marked their relatively minor claims, but did not bring to light the issues that concerned them most. On the other hand, the Duke tried to mitigate the situation, so that only the Landtag would pass the taxes. On Monday, August 5, 1566, the national Landtag in Königsberg began. In the afternoon, young Duke Albrecht Frederick, together with his court and old master superintendents, appeared to the gathered Estates in the great castle hall at 1 oclock in the afternoon. First, on his behalf, Chancellor Dr. Johann von Kreytzen spoke making proposals to the Estates on the subject of the proceedings, ${ }^{17}$ then these proposals prepared in writing read out the Duke's Secretary Kasper Dargitz ${ }^{18}$.

13 E.B. K.Kleinertz, op. cit, pp. 74-110.

14 Ibidem, pp. 213-214.

15 G. J. Kleiser, Der Wappenmaler Johann Hennenberger und seine Grundlagenden Genealogischen Arbeiten des 16. Jahrh. zur Erstellung Preussischer Stammtafeln bzw. Adelsbriefe, Toronto 1992 and original manusript 73, collection: Biblioteka Uniwersytecka in Toruń.

16 I present the first period of the Royal Landtag 1566 in more detail, despite the relatively poor activity, but for these reasons, because in the edition of Adolf Pawiński it is not as broadly reflected as the further period of the Landtag, connected with the activity of the Royal Commission. The material given here is contained in the volume Acta Borussica (AB), Leipzig 1732, vol. III, pp. 217-233. Therefore, I only exceptionally mention this source in footnotes. However, the material from other sources is consistently provided with footnotes.

17 Johann von Kreytzen - (Domnau 1516 - † Königsberg 1 V 1575), brother of Christopher. From 1524 he studied in Wittenberg, He later gained his doctorate in law and travelled extensively, in 1533 he was in Rome. When he got back, he started his service for Duke Albrecht. In 1536, he was sent to Inflants to help Margrave William. When he got back, he has been appointed Chancellor. He was the first indigene in this office. For 40 years, the whole foreign policy of the Duchy of Prussia was concentrated in his hands. He can be considered one of the most important Prussian politicians of the second half of the $16^{\text {th }}$ century. He represented Duke Albrecht at the Landtag. Dismissed in 1565 as a result of the intrigue of new Dukely advisors. He was reinstated as Chancellor before the Landtag of 1566 (Altpreussische Biographie (further - Altpr. Biogr.), hrsg. Ch. Krollmann, Königsberg 1941, vol. I, pp. 365/2-366/1).

18 Kasper Dargitz from Darłowo in Pomerania with the support of Pomeranian Dukes was taken in as a servant of Duke Albrecht. He took the oath of office on 3 October 1560. In 1565, as a result of intrigues directed against Balthazar Ganss managed to take the place of the Undersecretary of the Duke's Office. In 1575, he left 
On behalf of the Estates, the Starost ${ }^{19}$ of Pokarmin (Ger. Brandenburg), Anton von Borcke $^{20}$, responded by asking for a copy of the proposals which were then handed over to the Estates.

What did the proposals contain?

Sources do not provide this information, and undoubtedly the reasons why the Duke asks the Estates to enact taxes were given there.

Meanwhile, the Estates, fearing the danger coming from the west (the powerful armies of Paul Wobeser) ${ }^{21}$ decided to unite their efforts to defend their current political positions. By convening the Landtag, they were entitled to speak as part of the deliberations of individual curias. The sign of consolidation of the state party was the oral proposal of the nobility to meet with the cities of Königsberg. This proposal was made by the nobility as early as 7 August 1566 . The representatives of the nobility to the talks with the deputies of the cities were: Albrecht Truchsses von Wetzhausen ${ }^{22}$, Marshal of the Chamber of Deputies, Georg von der Gröben ${ }^{23}$, Georg von Kanitz ${ }^{24}$,

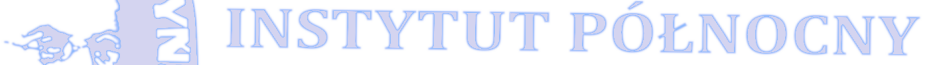

the office and was sent to Livonia to carry out alliance plans with Moscow. He died in 1582 (K. Lohmeyer (ed.), Kaspars von Nostitz Haushaltungsbuch des Fürstentums Preussen (further - HB), Leipzig 1893, pp. 176-177; Altpr. Biogr. Bd. I, p. 125).

19 Polish nobleman who was a governor of a particular region.

20 Joachim v. Borcke (born in Pomerania, $\dagger 11$ X 1572 Pokarmin / Ger. Brandenburg), brother of Anthony, starost of Pokarmin. Joachim arrived in Prussia in 1540, and in 1541 was accepted into the Duke's service. Married to Dorothea v. Schlieben. In 1549 the Duke promised him the office of starost for loans. In 1554 he already was the starost of Rybaki (Ger. Fischhausen). In 1556 he received a pledge on the office of Ełk (Ger. Lyck), in 1558 he was appointed to the office of Marshal. (Altpr. Biogr., vol. I, p. 71/2) and Geschichtsquellen des burg- und schlosgesessenen Geschlechts von Borcke, heraussgegeben Georg von Selle, vol. III, part I, Berlin 1907, pp. 766-777.

${ }_{21}$ Paul Wobeser was born in the Duchy of Pomerania. During the political conflict between the new councillors of Duke Albrecht and the Estates, the former recruited him to defend them. In the late summer of 1566, Webeser at the head of a thousand of mercenaries headed from Gdańsk to the Duchy of Prussia. The new councillors called him Marshal or Colonel. On their initiative, Duke Albrecht gave him a number of commissionings. The Prussian Estates and the Polish King demanded that Duke Albrecht dissolve the mercenaries. The Esates even passed a tax for the Duke so that he could make refunds for the claims of the mercenaries. During the trial of the new councillors in October 1566, Wobeser escaped from the duchy and his previously granted property was confiscated. In 1588 he was still on trial with the government of the principality for the settlement of financial obligations towards his debtors. (See: P.G. Thielen, Paul Wobser, Altpr. Biogr., Bd.II, Marburg 1969, p. 820).

22 Albrecht Truchsess von Wetzhausen of Gross-Klitten near Domnau stood at the Landtag in 1566 as a head of the state party. In 1567, he was given carge of Kreuzburg, previously owned by Skalich, and for a short period of time to Kaspar Fasolt. A. Truchsess died in 1573 (see: J. Voigt, Paul Skalich, der falsche Markgraf von Veona, Berliner Kalender für 1848, 22 Jhrg. p. 49; HB, p. 115)

${ }^{23}$ Georg von der Gröben - from May 24, 1541, probably until 1544, he was the administrator of the bailiff's office in Georgenburg. He was married to Margaret v. Lossau. In 1546 he became a Duke's councillor. In 1563 and 1567 he received from Duke Albrecht records in landed estates as compensation for his service. In 1568 he also appeared as a purchaser of landed goods (HB, p. 196, footnote 4 and p. 345 and Die Kartei Quassowski, Buchstabe G, Hamburg 1987, p. G-384).

24 Georg v. Kanitz together with his brothers Dietrich and Solomon received the property of Lauterbach and Schreinen in the district of Balga, in 1530 they asked Duke Albrecht so that they could receive it in a lifetime lease (HB, p. 15 and Urkundenbuch zur Reformationsgeschichte des Herzogtums Preussens, hrsg. P. Tschackert, Leipzig 1890, Bd.II, no. 721). 
Baltazar von Schlubhut ${ }^{25}$, Johann von der Gabelentz ${ }^{26}$ and other deputies. Representatives of the three cities of Königsberg responded favourably to this proposal and on Thursday, at 8 oclock in the morning of 8 August 1566, a joint meeting of noblemen's deputies and Königsberg's representatives was held in the Old Town Hall.

First, Albrecht Truchsses pointed out the causes of the Landtag and the widespread poverty and danger that threatens the country. The position of the Duke's councillors on the items to be discussed was also read out. Finally, there were some complaints about the state of the principality. It has been reported that from a certain source it is known that the Duke called Paul Wobeser into the service with a thousand-man army. In exchange, the Duke is to pay out 200 thousand Polish zlotys to his debtor within 6 months. If the debt was not paid, Wobeser would have the right, with the consent of the Estates, to "repress" the country's goods, i.e. to collect the remaining unpaid money through requisition. Adolf Pawiński adds that the towns complained that the Duke demanded 30 thousand thalers (silver coins) from them to pay for the mercenaries recruited by Wobeser ${ }^{27}$.

At this meeting the nobility and towns decided to prepare together a letter addressed to the Duke. The letter was to ask the Duke what he intends to do with the nomination of Wobeser. If the Duke excuses himself for not knowing anything about it, the Estates are to insist on bringing the initiator of the import of Wobeser to justice. In addition to this main issue, the cities have raised smaller charges, which have been included in the letter. The idea was for Hartmann Windeysen ${ }^{28}$ to secretly receive a few bollards and to build a porch from the castle to the old town church, which could be easily walked by a thousand and more people ${ }^{29}$. The Estates worked efficiently and on August $9^{\text {th }}$ the letter was prepared, read and accepted, and on August $10^{\text {th }}$ the Estates, through Albrecht Truchsses, handed the letter to the counsellors. A. Pawiński adds that Albrecht Truchsses asked "the lords who were at the side of the Duke", i.e. the superintendents, to join the authors of this writing of the nobility and cities ${ }^{30}$.

${ }_{25}$ Baltazar v. Schlubhut/Schlubutt, married to Barbara Fink von Finkenstein. The family had a property in the southern and western part of the Bartoszyce (Bartenstein) district, he had property in Wernikeim (HB, p. 107, footnote 5 and Die Kartei Quassowski. Buchstabe Sa-Sd, Hamburg 1989, p. S-290).

${ }_{26}$ Georg v. Gabelentz was also a son of Johannes, the Teutonic Knight, who after the secularization of Prussia received the office of Dąbrówno (Gigenburg) district and held the office between 1530-1539. After the death of his father, he and his brother Georg had to resign from this office. In return, they received compensation from the Duke in the granting of land. In 1544 Frederick v. Oelsnitz became starost in Dąbrówno. (HB, p. 345; Die Kartei Quassowski, Buchstabe G, Hamburg 1986, p. G-2; R. Flanss, Die von der Gabelentz in Preussen, Zeitschrift d. hist. Verein für Marienwerder, Heft 5, 1881, pp. 157-174).

27 Pawiński, DR, p. LXIV.

28 Hartmann Windeysen - no data available.

29 Pawiński, DR, p. LXIV states that the corridor a.k.a. porch was supposed to be built then. In fact, it was built a few years earlier (C.A. Hase, Herzog Albrecht von Preussen und sein Prediger, Leipzig 1879, p. 332), only then it has grown into a strategic importance. The same parliamentary file (APO V/3-6).

${ }^{30}$ Pawiński, DR, p. LIX. 
Meanwhile, as early as 12 August $^{31} 1566$, new unpleasant news came to the Estates from well-informed Gdańsk sources that Wobeser was threatening the country. For this reason, on the same day, at the castle of the Duke's advisors, the Estates asked for a hasty letter to the citizens of Gdańsk to stop him. Since there is no doubt that the new Duke's advisors are to blame for this recruitment, it should be made sure that they do not sneak away. In response, the Chancellor said that it would be an inappropriate humiliation for him to write to the Gdańsk people for help. Anyway, the culprits of this matter will soon be punished, because a committee from Poland is expected. Two facts are worth emphasising here. For the first time in the course of this Landtag, the Estates accuse new advisers, and yet the problem of new advisers will largely fill the entire history of the Landtag. The news of the arrival of the royal commissioners is equally important, as their activities will have a decisive influence on the course of the Landtag.

On August $13^{\text {th }}$ and $14^{\text {th }}$, the Duke's councillors discussed the letter given to them by the nobility and the cities. However, they were opposed to stopping Wobeser and keeping a watchful eye on the new counsellors. Therefore, in case of domestic excesses, the responsibility would fall on them. The Duke's councillors, who always entered the First Curia and gave it direction, should, in my opinion, be seen as a party of the middle ${ }^{32}$. This party is balancing between two enemy groups: a group of new councillors (the former Skalich group) and the Estates. The expression of this policy is the opinion expressed by them precisely in response to the complaint of the Estates of 12 August.

Meanwhile, on August $14^{\text {th }}$, the Landtag learned about new threats. A servant of Duke Charles Uhr ${ }^{33}$ was supposed to say in the winery of the Old Town Hall that a few case-shots had to be thrown into the crowd, and from among those sitting in the Town Hall one should cut off 50 heads (indeed, because the Landtag had about 50 members). Besides, said Uhr, all these matters will be dealt with thanks to this thousand reiters, and Prange the executioner has two swords prepared for this circumstance. Another message was supposed to come from a tailor who made a garment for a certain reiter. When the tailor expressed his concern about whether it would be paid for, the reiter dispelled his doubts, claiming that the money would soon be from "repression" on noble goods.

However, when these threats began to materialize, because many armies approached Königsberg (some of them were in boats, on the Pregola river, on August 15) the Estates handed a new letter to the councillors asking them to deliver it to the Duke, with the excuse of new complaints and with the threat that if the Duke

31 In AB, p. 223, a printing error. Instead of 12 August, it's 20 August.

32 Compare: L. Baczko, Geschichte Preussens, vol. IV, Königsberg 1795, p. 295.

33 Charles Uhr - no more details about him. 
does not want to prevent this danger, then the Estates will leave the Landtag going home. In the new situation the party of the middle behaved differently than before, accepting the request of the Estates and on Friday, $16^{\text {th }}$ August, together with four delegates of the nobility, three mayors of Königsberg and three deputies of smaller towns, went to the castle for an audience with the Duke. The Duke read the letter but did not give an answer and declared that he had to communicate with his counsellors. During the reading, he paid special attention to the end of the reading, when leaving the Landtag was mentioned. He only ordered the arrest of Charles Uhr, but he went to Tylża (Ger. Tilsit) two days earlier.

There was a small break in the deliberations for Saturday and Sunday.

On Monday, August 19, the Duke issued a decree for the three cities of Königsberg, in which he severely ordered the arriving reiters to be received without denying the inn or food. The Duke also demanded 150 archers from the citizens of Königsberg. Finally, he ordered the gates to be kept open in the city. The second demand for the transfer of 150 archers to the Duke, as the local guard, is to be understood as an attempt to disarm the city. With this Duke's letter, the Estates went to the councillors, stating that if the Duke upheld the decree, they would have nothing but to go home. They said that it was inappropriate to have foreign troops present during the Landtag and to ask for 150 archers. It is also very dangerous to keep gates open in the city in such turbulent times, especially because of threats. Pawiński writes more ${ }^{34}$. In the complaint of the Estates it was to be emphasized that the holding of troops at the time when royal commissioners with large armed forces are to arrive may cause misunderstandings and that the mercenaries may drag their troops past the city. Finally, the Estates promised to deliver the archers to the Duke for his guard. The councillors replied that it did not seem appropriate to them to ask the Duke for an answer at the moment, since tomorrow all these matters were to be clarified. However, due to the insistence of the Estates, the councillors decided to present this request to the Duke, first asking the Estates not to leave the Landtag and to persevere until the end. After lunch, Chancellor Johann Kreytzen communicated the answer to the Estates on behalf of the Duke. The Duke accepted the offer of the Estates to establish a personal guard with all kindness, but he did not need archers. The reiters will not stay in the city, but will move to the place of the show. The Duke was worried that the people have little trust in him. If he had known who was accusing him, he would have had him punished strongly, "if he ever thought of harming one of his people, the devil would have taken him away from his place." The Estates complained through the mouth of Albrecht Truchsses

34 DR, s. LXV. 
that such a threat is widely spoken about. Not so long ago, Johann Schnell's ${ }^{35}$ brother-in-law, Wojciech Freudener, ${ }^{36}$ was supposed to say that if the citizens of Knipawa do not stop attacking Schnell, then let them know that all slander and spitting on them will turn on them, which will cost them dearly. If they had not spared his mother and sisters who live in Knipawa, it would have resulted in a game that will be mentioned for a long time and no child will be left alive in the cradle. Eventually, the deliberations of that day ended with the establishment of the guard. At night, 25 people were to serve as guards with the Duke: 5 from the nobility, 8 from the Old Town, 6 from Knipawa, 4 from Lipnik and 2 from smaller towns. C.A. Hase ${ }^{37}$ adds that it was not meant to be a permanent service. The guards were supposed to gather at 7 oclock in the evening at the Old Town Square and go to the castle together.

On Wednesday, August 21, 1566, everyone gathered at the castle. The old and young Duke, councillors, new councillors Johann Schnell, Matthias Horst ${ }^{38}$ and Peter Cäsar ${ }^{39}$ have all arrived. First, Chancellor Johann Kreytzen spoke for a long time about love and faithfulness to the homeland. Then the Duke's secretary, Enoch Baumgartner, ${ }^{40}$ read the Dukess letter - a response to the allegations made since the beginning of the Landtag. This answer was already announced on 19 August. The text of the speech is given by A. Pawiński ${ }^{41}$. First of all, the Duke apologized to the Estates that while recruiting mercenaries, had not asked them for advise first. The cavalry rotas were promised to the Danish and Polish King. When the mercenaries set off on their way to Denmark, they were no longer needed by the Danish King, but were asked for by the Polish King, so they were sent back. Although the Polish King was badly informed about Wobeser's rota's intentions, he ordered Gdańsk inhabitants and their starosts on the Vistula River not to let them pass, but later, in a letter dated July 1, 1566, he asked the Duke to send his mercenaries to Inflants. Then it was no good for the King to say no to it. So the rotas would come, but only part will stay in Tapiawa (Ger. Tapiau), the rest will not stay long in this city. So the Estates can be calm about it. As for the armed guard of 100 people, it was in-

35 Johann Schnell came from the Duchy of Pomerania. In the opinion of the Prussian Estates, light-hearted. Lawyer by education. Duke's councillor ("new"). He was executed by a criminal court judgment of 28 October 1566 in Königsberg (HB, p. 155, footnote 2).

36 Freudener - no further details on him.

37 C.A. Hase, op. cit., p. 335.

38 Matthias Horst, who came from Mecklenburg, a Dukely councillor ("new"), previously in service of Duke Albrecht of Mecklenburg as a court chef. From the beginning of 1564 in Königsberg, he was left here for some time at the service of Duke Albrecht's father-in-law, Johan Albrecht of Mecklenburg. Executed by a sentence in criminal trial on 28 October 1566 (HB, p. 155, footnote 2).

39 Peter Cäsar - Saxon County Governor from Leipzig.

40 Enoch Baumgartner - Dukely Secretary of Duke Albrecht and then Duke Albrecht Frederik (HB, p. 65 , footnote 5, p. 180, footnote 5).

$41 \quad$ DR, pp. LXVI - LXVII. 
tended for Magnus of Denmark ${ }^{42}$ on the island of Saaremaa, and as for the 30000 thalers requested by the Duke of the city, there were mere persuasions, not threats. Finally, as for the "repressions" promised in the Wobeser agreement, the Duke reassured the Estates that this would not happen, and also as for the covered porch, the bourgeoisie's fears were exaggerated. At the end, the Duke called on the nobility and the towns to begin deliberations on the adoption of taxes. Albrecht Truchsses answered on behalf of the Estates, pointing out that because of the mercenaries the inhabitants of Prussia suffer material damage and that these troops do not want to move further. Finally, he mentioned that Hartmann Windeysen had taken down the guard post last night. He put both guards in a dark kitchen and, under threat, forbade them not to leave it for two hours. Albrecht Truchsses asked to punish Windeysen. The Duke promised this, but first he would listen to Windeysen. After this, both Dukes Albrecht and Albrecht Frederick and many others left the Chamber. Now there was Peter Cäsar's speech prepared in writing ${ }^{43}$, in which he stated that certain evil things were happening behind his back, and that he was cutting himself off from it. Albrecht Truchsses requested a letter from him at that time. He gave it to Truchses with a clear reluctance. Truchsses in turn was to familiarise with the content of this letter all participants of the Landtag. At the end of the day, the Chancellor read out a letter in Latin to all the Estates of Malbork (Ger. Marienburg), written by the royal commissioners, in which they announced their arrival.

The first period of the Landtag of 1566 ends in this way. The next two days were already expected to see the arrival of the Commissioners. In this first stage of the Landtag's activity, we find complaints from Estates related to the direct turbulence in the country. The Duke's party in one case tried to persuade (especially on the last day of the meeting before the arrival of the commissioners), in another it used threats against the Estates. It was a period of examination of the opponent's forces. The party was waiting for the arrival of Wobeser and Johann Albrecht of Mecklenburg ${ }^{44}$, the son-in-law of Duke Albrecht of Prussia, who were to strengthen its position.

42 Magnus (1540-1583) - Danish Duke, Duke-bishop of Saaremaa in 1560-1573 and Courland in 15601583, ruler of Livonia in 1570-1577 (W. Czapliński, Dzieje Danii nowożytnej 1500-1975, Warszawa 1982, p. 51).

43 Peter Cäsar - no data on him.

44 Johann Albrecht of Mecklenburg (1525-1576). In 1555 he married Duke Albrecht's daughter Anna Sophia. After 1563 he gained significant influence over the politics of his father-in-law (F. Schirrmacher, Johann Albrecht von Mecklenburg, Bd.I-II, Wismar 1885). 
The second period: From the arrival of royal commissioners to the submission of "Klag-Libell" by the Estates. (23 August 1566 - 7 September 1566) ${ }^{45}$

After receiving instructions from King Sigismund I dated July 20, 1566, the Commissioners went home to prepare troops for the road. On his way back from Lublin, Jan Kostka ${ }^{46}$, castellan of Gdańsk, learned about the march of Wobeser's troops towards the Duchy. The castellan ordered they should not cross the Vistula River. Wobeser stayed in Gdańsk, showing the local council documents that he was trying to help Polish King against Moscow and Sweden. Duke Albrecht, having learned about this, wrote to the bishop of Warmia, Stanisław Hozjusz ${ }^{47}$ and Kostka, to let go of Wobeser, which they did not want to do. However, Wobeser did it himself with his mercenaries who made a ferry on the Vistula and the road to the Duchy of Prussia was almost open. Meanwhile, the commissioners had not yet arrived, until finally Mikołaj Firlej ${ }^{48}$, the royal secretary, arrived in Malbork on 11 August 1566, and four days later Jan Służewski ${ }^{49}$, the voivode of Brześć-Kujawski and Piotr Zborowski, the castellan of Biecz..$^{0}$ They immediately started their duties, sending two letters: to the Prussian Estates with the notification of arrival and to the Council of Gdańsk, so that they would not let foreign soldiers in ${ }^{51}$.

On August 20, 1566, the Commissioners started their journey from Malbork to Königsberg ${ }^{52}$. On August 21 they arrived in Braniewo (Ger. Brunsberg), where Cardinal Hozjusz awaited them. On August 22 they were escorted to the border

45 Source material in AB, pp. 233-261 and 311-344, is the basis here. I put footnotes on messages from other sources.

46 Jan Kostka - († V 1581) studied in Königsberg and Tübingen, and perhaps also in Leipzig. So he knew German language. He had the following starosties: Malbork, Puck, Tczew, Lipno, and was the treasurer of the Prussian lands (4 March 1555 - V 1581). From Gdańsk Castellany (5 I 1556 - IV 1574) he moved to the Sandomierz Province. He was enjoying such a favour among the nobility that twice, once after the death of Sigismund Augustus, and then after the escape of Henry III of France, they wanted to make him King of Poland. He refused with Stefan Batory's support. He remained faithful to the Catholic Church (T. Glemma, Piotr Kostka, Toruń 1959, TNT. 81, pp. 11-15).

47 Stanisław Hozjusz (1504-1579), Bishop of Warmia, Cardinal, Polski Słownik Biograficzny, vol. X, 1962 1964, pp. 46-47.

48 Mikołaj Firlej from Dąbrowica (ca. 1531 - †1588). Lublin Voivode since 1588 and the head of various Małopolska heretics. Calvinist. (See Polski Słownik Biograficzny, vol. VII/1. Kraków 1948, pp. 10-12). W. Dworzaczek, Genealogia, Warszawa 1959, p. 264.

49 Jan Służewski - since 1562, Inowrocław voivode, then of Brześć-Kujawski, brother-in-law of Jan Kostka. (K. Niesiecki, Herbarz Polski, vol. VIII, Leipzig 1841, pp. 416-417, A. Boniecki, Herbarz Polski, vol. XI, Warszawa 1907, p. 353). Still in 1569, he was an Evangelist, later he converted to Catholicism. (W. Krasiński, Zarys historii powstania i upadku reformacji $w$ Polsce, vol. II, part II, Warszawa 1906, p. 262).

50 Piotr Zborowski $(\dagger 1581)$ - initially a Biecz castellan, then a Sandomierz voivode (1568) and finally Governor of Cracow (1574). That's what the Niesiecki writes about him: "Paprocki praises Peter for being far away from Catholic faith, even though he loved Catholic people and priests" (K. Niesiecki, Herbarz Polski, v. X, Leipzig 1845, pp. 130-131). He did not convert to Catholicism (W. Krasiński, Zarys dziejów powstania i upadku reformacji w Polsce, v. VII/1. Kraków 1948, pp. 10-12). W. Dworzaczek, Genealogia, Table 126).

51 This fragment after S. Bodniak, Polska a Prusy Książęce na schyłku rządów Albrechta, Rocznik Gdański, IX-X, 1937, pp. 264-265.

52 DR, p. 15. 
by the cardinal and spent the night at the castle in Pokarmin. Finally on 23 August they arrived in Königsberg with about 250 horses, greeted half a mile from the gates by the chief steward of young Duke, Jacob Schwerin ${ }^{53}$. Schwerin apologised to the Commissioners for the fact that, because of their illness, the two Dukes could not welcome them and that the Commissioners were placed not in the castle, but in the city. Adam Vetulani says that greeting the commissioners only by the chief steward of the young lord and living in an inn and not in a castle, according to the ceremony at that time, was an insult to the representatives of the landlord ${ }^{54}$. The commissioners have taken over the inns in Knipawa. From now on, their proper activity begins, the purpose of which is to follow the King's instructions. The arrival of commissioners was not welcomed by the court party and the new Duke's councillors bad it gave strength to the Estates and was supposed to lead to a joint action of the Estates with the commissioners of that party. The new period of the Landtag was filled with negotiations between the commissioners, Estates and Duke about instituting court proceedings against the new Dukely advisors, however, the Estates were quite cautious in their proceedings, leading to secondary complaints, which had nothing to do with state complaints. In the second period of the session of the Landtag, we should see the continuation of the activities of the Estates of the first period, with the fact that in their efforts they are now strengthened by the presence of commissioners from the landlord, the Polish King. The difference between the first and the second period of the Landtag sessions was the change in the tactics of the state party, which gradually moved from defence to attack. It was as follows.

The first negotiations between Commissioners and Dukely dignitaries took place on 23 August: Johann Kreytzen - Chancellor, Kasper Fasolt ${ }^{55}$ - burgrave, Johann Jacob Truchsses ${ }^{56}$ - chief steward. The dignitaries have submitted a request to

53 Jacob Schwerin - in 1551 he studied in Wittenberg, and was later appointed chief steward of the young Duke; remained in office until 1567, when he was replaced by Kasper v. Lehndorf, who at the request of the Polish King was to teach the young Albrecht Frederick the Polish language (HB, p. 128, footnote 3 and p. 251). Kasper v. Lehndorf-Mgowski son of Fabian I belonged to a Polish noble family from the Chełm region, Germanised only in the $19^{\text {th }}$ century (W. Kętrzyński, O ludności polskiej w Prusiech niegdyś krzyżackich, Lwów 1882, p. 129). Kasper Lendorff's father was the ancestor of this branch of the family, which lived in the Duchy of Prussia. Kasper, after the death of his father (1548), was the owner of the Duke's pledge Iławka (Ger. Preussisch Eylau), the starost of Bartoszyce, the chief steward of the young Duke (1567-1574), again the starost of Bartoszyce and Pokarmin (HB, pp. 250-251).

${ }^{54}$ Władztwo Polski w Prusiech Zakonnych i Książęcych (1454-1657). Wybór źródeł, ed. A. Vetulani, Wrocław 1953, p. 161, footnote 5.

55 Kasper Fasolt, son of Wolf, had properties in Iława (Ger. Deutsch Eylau) County, 18 June 1566, 1567, Until 1570, the elder above the Pasłęk (Ger. Preussisch Holland) bench and still in 1577 was called the Pasłęk Judge (HB, p. 167, footnote).

56 Johann Jacob Erbtruchsses v. Waldburg - Count, starost of Fishermen in 1555-1564, since 1565 the mayor, released from office in July 1566, then at the Landtag this year restored, starost of Szaki (Ger. Schaaken) since 1567 (HB, pp. 240-241; Altpr. Biogr. Bd. I, p. 837, S. Bodniak, op. cit. p. 243). 
the Duke that Elias Kanitz ${ }^{57}$, who came with the commissioners, should leave the principality. The commissioners did not want to agree to this, because Kanitz was not the enemy of the Duke, in their opinion, but wants to submit to a fair judgment (pares curie) at the court. In the end, the Commissioners agreed that Kanitz should not appear in public until Monday. On the same day, late in the evening, the Duke's service to the Commissioners announced the Duke's order that the Commissioners should appear next day for an audience at 8 oclock in the morning. ${ }^{58}$.

The next day, on 24 August, the Commissioners, agitated by the order of the Duke, called on the chief steward and the Chancellor" 59 . They declared that "they are not royal rulers, nor are they postal messengers, that they may be disposed of and sent away so quickly, but are royal commissioners, and should be free to act...." ${ }^{60}$. At the same time, the Commissioners asked that they would like to set off their messengers on Monday, 26 August. On the same day, August 24th, representatives of the Prussian Estates came to the commissioners, wishing them success in their plans through the mouth of Albrecht Truchsses von Wetzhausen - the marshal of the nobility. Commissioners in turn appealed to Estates, to give them advice and help, to stand by their side, and to communicate royal orders to them, but first they must present them to the Duke. The Estates have responded positively to this. This message was provided only by Adolf Pawiński ${ }^{61}$. It is valuable because it was the first time that Commissioners have come into contact with the Estates.

It was Monday, 26 August, when the Commissioners wanted to present the King's will to the Duke. The Commissioners, accompanied by Kasper Fasolt - the burgrave, Johann Kreytzen - the Chancellor, the two equerries - Johann Jacob Erbtruchsess and Jacob Schwerin, Dr. Christoph Jonas and Count Jonas von Eulenburg $^{62}$, went to the castle. The young and old Duke were already waiting for them on the stairs ${ }^{63}$. First, the commissioners greeted the Duke in the presence of old and new councillors: Horst and Schnell. They then requested a private audience to present the articles of the royal instructions. The Duke wanted at least six and then two councillors to be present, because he is elderly, has a weak memory and often cannot understand what is being said. This makes it all the more difficult for him to

57 Elias Kanitz, Frederick's younger brother, came to Dukely Prussia from Meissen. In 1565 he came into conflict with Duke Paul Skalich's favourite, whom he accused of falsifying his origins. He was outlawed for it. Then he went to Poland for a complaint. After the fall of the new councilors in 1567 he became the starost of Szczytno (Ger. Ortelsburg) (C.K. Hase, op. cit. pp.320-323 and HB, p.349).

58 DR, pp. 16-17.

59 Ibidem, p. 17.

60 Memorial PTT, p. 776: "They would not be royal chamberlains or post messengers, that they should be so hasty and praeserbiren time, but royal commissioners, who should also have their opportunity".

${ }_{61}$ DR, p. 18

62 Jonas Eulenburg, Count, son of Botha (+ 1565), in 1576-1577 the Starost of Węgorzewo (Angerburg), and in 1577-1582 the Starost of Bartoszyce, and until 1580 also the Starost of Pokarmin (HB,s. 13, footnote 1.)

63 DR, p. 20. 
respond to it, even if he had one article twenty times repeated. The commissioners did not want to accept this, because they wanted to judge the Duke's state of mind. Then Horst advised the Duke, however, to listen to the Commissioners. That's what happened. In addition to the old Duke Albrecht, the young Duke Albrecht Frederick also listened to the royal instructions. However, after reading a few points, the Duke decided not to listen anymore and even to propose to the Commissioners that one article be read to him several times and he requested that the text be sent to him in writing. However, the Commissioners did not want to do this by understanding that they would show their cards to new counsellors, who were, after all, accused in the instructions.

On that day, the Landtag was reconvened. There were voices to expel the reiters from the country. It was noted that the Duke disbanded the guards for which he had previously strived. It was proposed that, once the Commissioners have presented their questions and requests to the Duke, the Estates should present their complaints. Also on that day, the commissioners asked Johann Jacob Erbruchsses von Waldburg, the chief steward, as the highest dignitary, to convene the Estates the next day at one oclock in the afternoon, because they have orders and writings from the King for the Estates as well ${ }^{64}$.

In connection with this matter, the Commissioners, along with the representatives of the Estates, went to the Duke on 27 August asking him to allow the commissioners to hold separate meetings with the Estates. At their request, the Duke agreed to the request of the commissioners, giving a positive response from chief steward Erbtruchsses and burgrave Kasper Fasolt. It seems that this was a serious mistake on the part of the Duke. Instead of coming to an agreement with the Commissioners themselves, he allowed them to merge with the Estates. All the more so because there were more opportunities to communicate with the Commissioners than with the Estates. The Duke wanted to oppose his authority against united forces of Estates and commissioners. It was naturally absurd for him to be able to emerge victorious from this clash. At this joint meeting, Albrecht Truchsses von Wetzhausen - the marshal of the noble house presented the complaints of the Estates which had been raised the previous day during the sessions of the Landtag. Finally, it was agreed that a joint state session with the commissioners would take place on the same day in the cathedral church in Knipawa at two oclock in the afternoon.

At that hour, councillors and deputies from all the Estates appeared. Soon the Commissioners arrived and were greeted by the burgraby - Kasper Fasolt ${ }^{65}$, the

\footnotetext{
64 DR, p. 21.

65 Kasper Fasolt, Wolf's son, had properties in Iława County. From 18 June 1566 to 1567 a higher rank bulgrave, until 1570, the elder above the Pasłęk court and still in 1577 was called the Pasłęk Judge (HB, p. 167, footnote 2.).
} 
Chancellor - Kreytzen, the chief steward - Joahan Jacob Erbtruchsess and count Jonas von Eulenburg. Then they were taken to the choir of the cathedral church and took their seats there. On the first chair Jan from Służewo, on the second chair Jan Kostka, on the third chair Piotr Zborowski, on the fourth chair Mikołaj Firlej. The Prussian Estates stood around the chairs. At that time, Jan Kostka gave a carefully prepared speech. He said that the King had heard the news that things were wrong in Prussia. He knows that this is not the fault of the Duke, but of the reckless and insidious people who control the Duke in his old age. Therefore, in order to help this country and the Duke, his relative, the King sent his commissioners here with full authority. Since the Commissioners are not aware of the reasons for this evil, they are asking the Estates and dignitaries to respond to it. They themselves desire nothing "but the good of His Majesty the Duke and his province: that the Elderly Duke, whom His Majesty considers to be the father, may in blissful peacefully end his old age, the younger one, whom His Majesty treats as his son, that after the death of the Elder Duke he may find all things well arranged and all things calm, and all subjects may in the meantime enjoy peace."6 Kostka then presented the points of the royal instruction and handed out letters intended for the Estates $s^{6}$. The instruction of July $20,1566^{68}$ provided how to make a speech to Duke Albrecht and how to justify interfering in the internal affairs of the fief land. Then the instruction recommended the greatest possible gentleness towards the Duke in order to maintain "the sweetness of the relationship that occurred between Sigismund, his cousin, and the man broken by old age and illness". The instruction was that the Commissioners would have a conversation with Hozjusz, and then, on arrival in Königsberg, would spend 1-2 days studying the situation and then ask for an audience with the Duke. In the audience they would say that bad news of the riots in the country was coming to the King, and that the King sent them to acquaint the Duke with what he thought. The instruction also stated that if it is possible, for reasons of his health, to speak further with the Duke, then the commissioners should present the royal view on these matters. First they would explain the reasons for their arrival. At this point, they were supposed to remind the Duke about royal letters, about the April mission of Hozjusz, about the fact that the Duke did not answer to it in writing despite his promises, and also the Duke's deputy in Poland, Wenzel Schack von Stangenberg ${ }^{69}$, had nothing to say in this respect. In the absence of any news from the Duke, and with the complaints of many of the Dukely subjects, the King sent his commission-

66 DR, pp. 21-22, translation by A. Vetulani, Władztwo Polski, pp. 170-171.

67 A. Pawiński, DR, p. LVII.; A. Vetulani, Władztwo Polski, p. 171, footnote 22 explains that these were powers of attorney, a letter of intent and instructions for royal MPs.

68 DR, pp. 3-11 instruction, pp. 11-12 power of attorney, pp. 12-14 Iron letter.

69 Wenzel Schack von Stangenberg, doctor, Duke's deputy in Warsaw, married to Kristina, daughter of Chancellor Joahann Kreytzen. In 1575 he became Chancellor. (HB p. 156, footnote 6 and pp. 340-341). 
ers here for the good of the Duchy of Prussia. The Instruction noted that the King did so not by title, but because of the love and kindness he had for the Duke. It then lists all the abuses and shortcomings that have taken place in the Principality of Albrecht.

1. Old, faithful counsellors have been removed, and new and evil have been called, who have stripped the Duke of his possessions and spread rumours that they control him.

2. Subjects complain about new solicitors, in particular about their frequent litigation and the imposition of large taxes.

3. The question was why at the Augsburg Landtag, where the abolition of banishment was considered, there was no Duke's deputy. At this point, the King reminded that in the past the Duke could even look after other people's affairs.

4. The subjects were forced to swear an oath of allegiance to certain German Dukes (Brandenburgers on January 18, 1566) ${ }^{70}$ without the King's consent, although the Duke made some reservations.

5. The last tax was imposed, not passed in the Landtag.

6. Castles and estates were granted under the heritage law to foreigners without the royal consent and knowledge, i.e. in violation of treaties (Article 15 of the Cracow Treaty).

7. Paul Skalich's lampoons ${ }^{71}$ against the emperor were spread with impunity, which adversely affects relations with the emperor and is contrary to the interests of the King and the Duke.

8. Apparently the Prussian administration was transferred to a foreign Duke (John Albrecht of Mecklenburg) without the King's permission.

9. There is also talk of changing the will of Duke Albrecht.

These are the works of the new counsellors. So let the Duke, the instruction said, repair the condition of the Estates with support of the commissioners, and restore the old counsellors, decree the goods distributed to strangers, impose less tax, uphold the old will and do not appoint a governor, because the King will never agree to that. This speech was to conclude with a statement that the King was particularly anxious to preserve the honour of the old Duke and to maintain peace in the legacy of the young Duke. The project of Elijah Kanitz, the main opponent of the governments of the new councillors, aiming at the establishment of a Polish governor in the Duchy of Prussia, was not included in the instruction. Because Germaniae."

70 DR, p. 7, "Yus iurandum expressum est a subditis Illustritatis V. de obedientia nonnulis principibus

${ }^{71}$ Paul Skalich (1534 Zagreb - 1575 Gdańsk), a scholar and adventurer, a favorite of Duke Albrecht. He escaped from Königsberg avoiding the trial (J. Voigt, Paul Skalich der falsche Markgraf von Verona, Beliner Kalender für 1848, 22 Jhrg. pp, 1-88; G. Krabbel, Paul Skalich ein Lebensbild aus den 16. Jahrhundert, Münster 1916). 
"there was no... certainty whether the royal governor, imposed against the privileges, will meet with the voluntary recognition of the Prussian nobility..." ${ }^{72}$. The placement of the Polish Commissioner could result in a merger of the Prussian Hohenzollerns with the Reich against Poland and create additional danger in the north. S. Bodniak ${ }^{73}$ justifies this kind of Polish policy by the fact that in Prussia the prevailing layer was German or Germanized nobility and bourgeoisie, i.e. the foreign element. Therefore, he believes that the Polish governor would be badly received here, and that the voice of Elijah Kanitz was not an expression of the voice of the Prussian nobility in general.

After reading the royal instruction, Chancellor Joahann Kreytzen took the floor, trying as much as possible to counterargue the royal accusations contained in the letter. Kreytzen represented the centre party. He said that the old counsellors had been removed and new ones called, but that was the will of the Duke, and who could have resisted him. No one was forced to pay homage to the Brandenburgers. As for the tax, it is true that it was imposed, but it depends on the will of the Estates, which can either pass it or reject it. That is why the Landtag has been convened. In the matter of sending a deputy to the Reich's Landtag, the Chancellor explained that the Chancellor Joahann Jacob Erbtruchsses and Doctor Christoph Jonas ${ }^{74}$ were supposed to be there but because of the difficulties in the country, they had to stay. At the Reich Landtag, they were to be replaced by Dr. Aquila ${ }^{75}$, who was in the service of the Duke of Leipzig. Why he did not fulfil this task, we do not know. As for the governorate, there were such voices, but he does not know how it actually happened. The Old Testament was indeed taken from Tapiawa by Dr. Laurentius Kirchoff, ${ }^{76}$ but what happened to it is not known. Finally, with regard to Elijah Kanitz, it is true that he was denied the pares curiae court, but he was given the opportunity to defend himself before the ordinary court. Kreytzen's speech was based on his office rather than personal views, which he clearly distinguished in his speech about Kanitz when he said that the Duke demanded that Kanitz leave the country, but that is not his opinion, because Kanitz is his friend ${ }^{77}$.

72 S. Bodniak, Polska a Prusy Książęce, p. 262.

73 Ibidem, pp. 263-264.

74 Christoph Jonas - born 1510 in Königsberg, $† 21$ II 1582), son of Nicholas, councillor of the Old Town. He studied at the cost of the Duke of Wittenberg, and in 1543 in Italy he was awarded the title of Doctor of Rights. In 1544, in support of Fillip Melanchthon became the first professor of law at the newly founded Royal University, in 1548 its rector. In 1554 he left the college of professors and in 1562 he became a Vice-Chancellor. He enjoyed a special trust of the Duke. He participated in the amendment of Culm Law (Altpreussische Biographie, vol. I, p. 309; HB, pp. 254-255).

75 Aquila-dr, no data.

76 Dr. Laurentius Kirchof, came to Prussia from Rostock. He was trusted by Duke Johann Albrecht of Mecklenburg. After resignation of Johann Kreytzen was the Chancellor of the Duke for several months in 1566 (see J. Małłek, Geneza sejmu 1566 r., p. 513).

77 Memorial, PTT p. 765. 
The same speech was given by chief steward Erbtruchsess. These speeches have caused uproar among debaters who were dissatisfied with them. There were screams from both sides. Finally, when it calmed down, Albrecht Truchsses the Speaker of the Chamber of Nobility appeared. He said that the gravamines put forward by the Commissioners were more than real. He reserved, however, that it is not this pious and honourable master who should be attributed to this poverty, but only to the reckless and selfish villains who have put everything on such a path. Then, discussing the royal allegations, he subsequently confirmed their credibility. After that, the Commissioners heard a new complaint, namely: the money from the adopted tax to buy out the castles, after only two were bought out, on the advice of the new councillors were spent on other purposes ${ }^{78}$. Finally, Truchsses accused the Chancellor and the chief steward of not wanting to know the truth. Now it was the turn of the cities. They were supposed to express their opinions. The Mayor of the Old Town, Kasper Nepfel, ${ }^{79}$ did not want to speak, justifying his lack of powers of attorney from small towns. The Mayor of Knipawa, Johann von Lohe, ${ }^{80}$ although he did not own any of these, nevertheless took the floor and stated that he personally fully agreed with Albrecht Truchsses' remarks. He also said that it was not the fault of the Duke, but of evil people, new counsels, and especially of Schnell, who is a wicked man, perjurer and divine dissociator. Schnell has caused many misfortunes to the city of Knipawa. This was followed by the speech of higher rank burgrave Kasper Fasolt, who was offended by the statement of Johann von Lohe about the new counsellors, because he was also appointed to the burgrave's office not long ago (18 June 1566). In response, Johann von Lohe reassured the burgrave that he had nothing against him. Then the mayor of Lipník was to speak, but he hid behind the lack of powers of attorney and asked to be able to consult his own people first. Then there was a city council. It resulted in a speech of a mayor of the Old Town, Kasper Nepfl, who said that everything that the royal commissioners and Albrecht Truchsses said was true and there are examples of it. In this way, the cities, after some hesitation, expressed views consistent with the nobility. In this situation, neither Chancellor Johann Kreytzen nor chief steward Erbtruchsess wanted to close the session, as they would have found themselves in a situation that approves of what has been said here. So Marshal Albrecht Truchsses did it. He thanked the commissioners for their efforts, acquitted the Duke, and blamed everything on the bad people, who "by order of the devil" advised the Duke. Those evil people who

8 DR, p. 24.

79 Kasper Nepfel, in 1557 he was the Duke's secretary and in 1566 the mayor of Old Town of Königsberg (HB, p. 196, footnote 2).

80 Johann von Lohe, Mayor of Knipawa, no further information available. 
are the cause of this poverty are: Johann Funck ${ }^{81}$, founder, Schnell - advisor, Horst - continuator and Steinbach ${ }^{82}$ - executor. Finally, Albrecht Truchsses asked the Commissioners, with the power of royal authority, to arrest them and bring them to justice. He was followed by a guest appearance of Elijah Kanitz who arrived with Commissioners. He stated that he had an honourable case with Paul Skalich, but that he had escaped, so he could not assert his right. The same applies to Horst and Schnell, who did not allow him to court of peers, and the latter ordered for him a gallows, which he expects Schnell will not miss.

Jan Kostka answered that they were here to do justice to everyone, to protect their privileges, to allow them to come to fair treatment. It was then that the discussion began on what form to take in order to settle the accused's case. The Estates did not want to give any loud advice on this matter. They were afraid of the vengeance of the new councillors and firmly stated that the Commissioners would find their own way out. At that time, the Commissioners considered it appropriate to sue the new counsellors and judge them at home lands. The Estates were to choose a special committee to participate in the trial of the new counsellors ${ }^{83}$. The next day, they were given lawsuits. "This first step of the commissioners may have been too bold, or at least too violent and too hasty, to have prompted the Duke, or rather his advisors, immediately to oppose a strong decrease in the power of the chief judge, as the Duke himself was within his own country," wrote Adolf Pawiński ${ }^{84}$.

On 28 August the Duke held a meeting with the councillors and then sent Secretary Dargitz to the commissioners, who asked the commissioners for a meeting. It took place that day at 1 o'clock in the afternoon. In addition to the Commissioners, the Estates and the Chief Superintendents participated: chief steward Johann Jacob Erbtruchsses zu Waldburg, burgrave Kasper Fasolt, Chancellor Johann Kreytzen and Dr Christoph Jonas. Dr Jonas, on behalf of the Duke, gave a speech in which he accused the Commissioners of entering into the powers of the Duke, conducting negotiations with the Estates in the absence of the Duke. In his speech, he expressed his reluctance and bitterness because of the diminished digni-

81 Johann Funck, (born 7 II 1518 in Nuremberg, suburb of Wöhrd, † executed 28 X 1566 in Königsberg). He studied at Wittenberg. In 1547 he was in Prussia, where he became the parish priest of the Old Town and a court preacher. When Osiander arrived, he joined him. At a synod in Prabuty in 1556, he was forced to take the side of the Augsburg confession. Proud Funck vetoed this humiliation, creating a new Osiander church order in 1558. After the arrival of Paul Skalich in Prussia, he gave him priority at the side of the Duke and joined his party. He was an expert in theology and history. (Cf. Real-Encyklopädie für Protestant Theology and Kirche, ed. J.J. Herzog and G.L. Plitt, v. 4, Leipzig 1879, pp. 716-719 (by W. Möller), and Altpreussische Biographie, published by Ch. Krollmann, vol. I, Königsberg (Pr.) 1941, pp. 202-203 (author: Weder).

82 Johann Steinbach - (born in Annaberg, Saxony), librarian, Dukely councillor. Lawyer, the head of the secret registry. Together with Schnell an intermediary in loans to a Duke from the bankers of Gdańsk and Szczecin. Expelled from the country in 1566 by a criminal court judgment (HB, pp. 161-162, footnote 5).

83 DR, p. 25.

${ }^{84}$ Pawiński, DR., p. LXXIII. 
ty of the Duke. The Commissioners defended themselves as follows: they follow the King's instruction to negotiate with the Estates if it is not possible with the Duke. If the Duke had said that he could hear something 20 times and still remember nothing, then they could only follow the instructions. In any case, the Duke's councillors were present at the meeting with the Estates. Finally, they said that the King had to intervene when the lands were alienated and governorship was established, which was contrary to the Treaty of 1525 . And if the situation requires, they threatened, the King will reach for a weapon ${ }^{85}$.

Dr Jonas answered in conciliation to that after the meeting. The Duke does not have the old cleverness of mind, but he is not devoid of mental powers. Sometimes he can talk a lot, e.g. today he spoke about his rights and that he wants to go to his relatives. It was a threat to the Commissioners. It is true that he is susceptible to influence, and he has been for a long time. Finally, Dr Jonas called on the Commissioners to stop suing and negotiating with the Estates and to deal with the Duke and the councillors, and if the Duke does not want to do so, they can manage the matter themselves ${ }^{86}$. The Commissioners replied that they had to ask the Estates about it with which the negotiations had begun.

Meanwhile, on that day, the Landtag held its deliberations and elected the aforementioned committee, which was to stand alongside the commissioners during the trial against the new advisers. The following persons entered the committee:

\section{Old Town:}

Kasper Nöpfel - Mayor, Merten Kalau, Bartholomeus Bartsch from the courthouse:

Christoph Rabe ${ }^{87}$, Johann Ungerman, Thomas Richter

from the common people:

Wendel Hofmeister, Georg Weymer

\section{Knipawa:}

Johann von Lohe mayor, Michael Wiesner, Peter Glogau

from the courthouse:

Dirck Mundfort, Wilhelm Platte, Gregor Volmesser

from the common people:

Michael Möller, Frederick Mundfort

85 DR, p. 27.

86 DR, p. 28.

87 Christoph Rabe - Mayor of the Old Town. He had 11 brothers. His wife was Eva Elvert Mavin, daughter of the mayor of the Old Town of Königsberg. (J. Gallandi, Königsberger Stadtgeschlechter, Altpreussischer Monatschrift, Bd. 20, 1883, p. 211; op. cit., p. 451) 


\section{Lipnik:}

Hieronim von Stein - Mayor, Barthel Hohendorf, Jeronimus Köseler from the courthouse:

Simon Krüger, Brosin Pleppin, Adam Heidenreich

from the common people:

Elijah Lichtenau, Bastian Klue

\section{From nobility:}

Albrecht Truchsses von Wetzhausen - Speaker of the Chamber of Nobility Baltazar von Schlubhut, Georg von der Gröben, Johann von der Gablentz, Bastian Kobersche ${ }^{88}$

Melchior Lesgewang ${ }^{89}$

\section{From small towns:}

Merten Pottien - Mayor of Bartoszyce

Christoph Klee - from Welawa (Ger. Wehlau)

Johann Amende - writer from Morag (Ger. Mohrungen)

Johansen - writer from Tylża (Ger. Tillsit).

It was noted that this committee is appointed only to deal with the issue of new advisers. In other cases, reference should be made to the wider public. The elected have taken an oath not to harm the Duke and the Principality, but to judge faithfully and honestly for his sake. Whoever opposes it, let the earth swallow him up like: Korah, Dathana and $\mathrm{Abiram}^{90}$, and they confirmed Amen three times.

In the afternoon, a joint meeting was held at the Commissioners' Inn, which included, apart from the hosts, councillors and Estates ${ }^{91}$. The Estates were supposed to answer what they thought about the Duke's project so that the negotiations would be conducted by commissioners directly with the Duke. It is understandable that the Estates were not very eager to give a positive answer, and therefore the answer was postponed until the time when they found out whether the counsellors joined the resolution adopted in the cathedral church (i.e. suing new counsellors). Meanwhile, the councillors answered no and started to accuse the Marshal of the Chamber of Nobility, Albrecht Truchsess, of allowing himself to speak too much at that time. Word fights took place between Albrecht Truchsses and Chancellor Johann Kreytzen and chief steward Erbtruchsessen. The last one, upset, ran out of the

\footnotetext{
88 Bastian Kobersche - in 1573 became the starost of Nidzica (Ger. Neidenburg) (HB, p. 348).

Melchor Lesgewang - had property in the Bartoszyce starosty (HB, p. 107, footnote 2).

Gdansk Bible, Old Testament, Numbers 16.

91 I present this meeting mainly for A. Pawiński, DR, pp. 28-29, which is the most clear.
} 
building, slamming the door, which the Commissioners thought was a misconduct. In the end, however, the commissioners, on the advice of the Estates, agreed that the Duke should administer justice to the new counsellors, and not them, naturally in their presence, but to do so immediately. If that did not satisfy the Commissioners, then they would apply lawsuits to the new counsellors. With this concession from the commissioners, the Duke thought he would rip their guns out of their hands. In fact, it seemed like it would happen, but the Duke found himself in the difficult role of a judge, which he did not want either, but in order to save his allies, he undertook to do so.

On that day, Albrecht Truchsses asked for the keys to the castle. He announced that the new councillors were managing the artillery and were going to eradicate the commissioners. This concludes the session of the Commissioners gathered in the inn. The Duke took the initiative again. The commissioners stood aside. The work of the 34-member committee ended in one day. Already on 29 August, the Duke told the commissioners through the chief advisers that he wanted to hear all the complaints on 30 August, i.e. to start legal proceedings against the new advisers. At the same time, he ordered a court of peers for Elijah Kanitz. In these steps, we should see some concessions to the Commissioners and a desire to comfort them. At the same time, he gave Elijah Kanitz a safe conduct. This was handed over to the Commissioners, but they did not accept it, because Kanitz - they said - is enough of a royal safe conduct. Then Kanitz was persuaded to take it, which he did after a long hesitation with the explanation that he was taking it not for his own safety, because for this he had enough of a royal safe conduct, but for the glory of the Duke.

On that day, the Landtag continued its deliberations in the Town Hall. It was necessary to think about how the Estates should act against the new advisors on the next day. They were afraid of the bias of the court. Between the lines of the diary of the Royal Landtag one can read that there was no certainty nor unity among the Estates, since the commissioners expressed themselves as follows: "We bring you war or peace with us, choose what you want. You want to stay with your privileges, your judgments, your laws, in peace and quiet - then follow this. That is why we came here to help you. If you do not want to, consider what might happen to you." The letters written to Gablent $z^{92}$ and Rauschke ${ }^{93}$ from the three castles bordering with Mazovia were then read out. Their content showed that the Mazurians on the border are standing in the force of 3,000 troops and threaten to come to them soon. Here we see what forms of pressure have been used to consolidate the Estates

92 Probably Johann Gabelentz, starost of Dąbrówno in the years 1530-1539 (HB, p. 345)

93 Probably Alexander Rauschke, Starost of Działdowo (Ger. Soldau) in 1566 (HB, p. 352) 
and turn them against the Duke. At the same time, the Landtag heard about the Duke's alleged departure and asked the commissioners to persuade him not to do so. In the afternoon, Albrecht Truchsses von Wetzhausen informed the Estates of the composition of the court appointed by the Duke. It consisted of: chief steward - Johann Jacob Erbruchsess von Waldburg, chief steward of young Duke - Jacob Schwerin, Dr Christoph Jonas, Dr Nicolaus ${ }^{94}$, Dr Ambrosius Lobwasser ${ }^{95}$, Jonas von Eulenburg, Sigmund Kerstendorff ${ }^{96}$ - the mayor of Szaki (Schaaken), Nikolas Sparwein ${ }^{97}$ - the starost of Tapiawa. The composition was not final. Truchsses commented on the names of these elected judges, namely that they would probably not be acting as judges of the new counsels, but as their attorneys. Finally, a debate was held on the person of the prosecutor who is to speak on behalf of the Estates. The choice was of Matthias Bögner ${ }^{98}$ from Elbląg. Albrecht Truchsses then communicated to the Estates to support them morally that the royal commissioners had sent secretary Jan Dmitr Solikowski to the King by post $^{99}$. On the following day, Friday, August 30th, the court was held at the castle. The Commissioners finally saw what they had been striving for since the beginning of their activities. Duke Albrecht was sitting at the table, on the left hand there were commissioners, and on the right hand there were young Duke Albrecht Frederick and his advisors, who were to be judges, Erbtruchsses chief steward, Kasper Fasolt burgrave, Christoph Jonas doctor, mgr (M.A.) Lukas Dawid ${ }^{100}$, Dr Lobwasser, Dr Rodt ${ }^{101}$, Dr Clement ${ }^{102}$ official, Dr Nicolas Germanus ${ }^{103}$, Nicolas Sporwein - starost of Tapiawa, Sigmund Kerstendorff - Mayor of Szaki. The judge was also supposed to be Chancellor Dr

94 Dr. Nicolaus - an unidentified person

95 Ambrose Lobwasser, 1515-1585, born in Saxony. He studied in Leipzig, Paris and Bologna. Since 1563 a professor of law at the University of Königsberg. Author of the translation of David Psalms (Neue Deutsche Biographie, Bd.14,Berlin 1985, p. 740 and n, P.G. Thielen, Die Kultur am Hofe Herzog Albrechts (1525-1568), Göttingen 1953, p.146).

96 Sigmund Kerstendorff-Kierstanowski (probably a Pole), in 1566, 1567 a national mayor of Szaki. His signature was among the witnesses of the last will of Duke Albrecht, dated 14 May 1566. He was considered a supporter of the new counsels and Duke Johann Albrecht of Mecklenburg. During the trial of the new advisers, he represented by Duke Albrecht (HB, p. 38, footnote 3 p. 351).

97 Nicolas Sparwein - starost of Tapiawa in 1565,1566 (HB, p. 57, 200, 206, 352).

98 Matthias Bögner - studied in Wittenberg, lawyer, secreator of the Elbląg City Council (See E. Carsten, Geschichte der Hansestadt Elbing, Elbing 1937, pp. 330-331,336).

99 Jan Dymitr Solikowski (1539-1603). Studied in Rome, then he was secretary to Zygmunt August and then to Stefan Batory. Since 1583, the Archbishop of Lviv. (See S. Orgelbrand, Universal Encyclopedia, Volume XIII, Warszawa 1902, pp. 620-621). A separate monograph was written by W. Nehring, O życiu i pismach Jana Dymitra Solikowskiego, Poznań 1860.

100 Lucas David (1503-1583), historian, chancellor of the bishop of Chełm, then counsellor of Duke Albrecht. Author of the Prussian Chronicle. (P. G. Thielen, op. cit., , p.163)

${ }_{101}$ Rodt. Dr - no data.

102 Clement, Dr. Probably Klaus Schwarz, who was called Clement - a long-time Dukely official of the pension camera, from the beginning of 1566 to the summer of 1567 was in charge of the pension camera. He was to some extent responsible for the commercial machinations of the new advisers (HB, p. 146, footnote 1).

${ }^{103}$ Nicholas Germanus, dr., no data. 
Johann Kreytzen, but he asked for an exclusion because he wanted to take part in the accusation part. At that time it was agreed that the judges would also be: Bartholomew Richau ${ }^{104}$ and Faustein Nimptsch ${ }^{105}$, but the Estates protested against it, claiming that they find them suspicious. At that time, the burgrave Fasolt wanted to remove the collected Estates from the hall, but they remained as per request of the Duke. Before the session with the Estates had even begun, the commissioners had turned to the Duke with a justification to sue the new councillors. This was not due to their bad will, but to the fact that the Duke did not want to negotiate with them. At the same time, they pointed out that the new councillors are people of low origin and reckless and the commissioners could not negotiate with such people.

After the meeting, Chancellor Johann Kreytzen, on behalf of the Duke, replied that the Duke accepted the Commissioners' justification, thanked them for their efforts and asked for a written complaint. ${ }^{106}$. Kostka replied to the request of the Duke that they were here not only to write and speak, but also to remove evil with actions. A nervous Duke interrupted the speech explaining that he could not talk about these matters in a presence of such a large number of people, It was then disputed whether the Commissioners would act as auditores and spectores or as censors. The commissioners regarded themselves as censors, the Duke as listeners and observers. The discussion did not bring any results and each side stayed the same. A proper part of the judicial process, the filing of complaints followed. They were submitted on behalf of the Estates by Albrecht Truchsses - marshall of the Chamber of Deputies. He did not mention anything about the complaints he had filed so far, but he came up with something new, namely he attacked Johann Funck and Matthias Horst, the head of the new counsellors, in the absence of Skalich. On August 28 Funck was supposed to say to the Duke that there are no faithful subjects in the country and he should go with the young Duke to his relatives. Horst was supposed to be present. Since it was an insult and a defamation to the Estates, Truchsses demanded the arrest of the defendants. Funck replied briefly that he had been awaiting such an unjust accusation. Then, after his departure and after a conversation with Horst, he returned and asked that, due to his clergyman and office condition and his voice indisposition, he be given a lawyer to answer the question. Then Albrecht Truchsses arrogantly attacked him, saying that this was not about an

${ }^{104}$ Bartholomew Richau - son of the Mayor of the Old Town, Nicolas Richau, who is at the approval of the Krakow Treaty of 1525 by the Prussian Estates. Bartholomew Richau was a city writer in 1540, and from the beginning of the year 1566, he was Duke's councillor. (Lt. Altpr. Biogr. hrsg. v. K. Forstreuter and F. Gause, Band II, Lieferung 4, Marburg/Lahn 1961, p. 555.)

${ }^{105}$ Faustein Nimptsch younger, shortly after the death of his father (1556), a pension camera counsellor. He was in close relationship with Skalich and Horst. (HB, pp. 247-248 and W. Meyer, Jacob Quandt and Faustein Nimptsch two Königsberger councillors from the time of the Osiandrischen disputes, Altpreussische Geschlechtenkunde, 3 Jhrg., issue 1, 1929, pp. 83-89 i J. Gallandi, op.cit., p. 211); Altpr. Biogr., v. II, p. 472/2.

106 Pawiński A., DR, p. LXXVII. 
office, but about a person. This is a criminal case. He was always capable of talking nonsense anyway it was enough if he simply answered yes or no. Then the Duke gave a verdict through the mouth of Dr. Christoph Jonas to answer yes or no, to which Funck stated that he must therefore answer, but neither affirmative nor negative. He said he did not want to deal with the Estates because they are too big for him. He knows that there are many noble people among the Estates, and he knows that there are also his enemies. This is partly because of the Osiandrov dispute and partly because he was not so zealous and did not shout at their declaration: "I like" or sang: "Dear Junkers, this is the truth." Two days ago, he was sued as a troublemaker of the country, and now new complaints are being made, in order to destroy a poor man such as him. Finally, he asked to show him the one who slandered him. Then Albrecht Truchsses appeared and found that Funck accused him of having taken action against him, not the Estates. In fact, he had nothing to do with him, but the Estates were against him and he was merely following their will. The crowd shouted: "Yes! Yes!" and demanded that Funck give the answer: "yes or no." Then Funck, apparently nervous about all this, began to repeat his previous speech, and finally said that the Estates were too great for him and added, "What devil wanted me to call them at that time?" Many Estates called out these words: "Let him take you, let him take you, let him take you, as an incurable pope." The hatred of the Estates towards Funck, created in the times of Osiander, has unleashed. Horst spoke little and asked for him to be excluded from the prosecution because, according to the accusation, he was to be the only witness to Funck's speech. So he wanted to act as a witness. This statement was interrupted by the Duke, who demanded that Funck answered yes or no, to which he replied no, that is, he did not advise the Duke to flee the country. In this situation, the Estates must have given names of people from who they knew about it. They were: Merten Kalau ${ }^{107}$ and Christoph Preuss ${ }^{108}$, relatives of the councillors of the Old Town. The session was adjourned and the two townspeople testified that they knew about it from Bartholomew Richau, who was appointed as a Duke's counsellor six months ago. They said he told them in secret. After this statement Richau was wanted, but he was not there, so his testimony was postponed until the next day. The Estates demanded the arrest of the defendants. The Duke considered it superfluous and ordered the defendants to take the oath by hand that they would appear tomorrow. After Funck and Horst took the oath, Eliasz Kanitz took the oath and asked for the court of the peers and announced that he wanted to take legal action against Schnell. The former was promised to him and the latter was postponed until later.

${ }^{107}$ Merten Kalau - no data available.

108 Christoph Preuss - no data available. 
The next day, $31^{\text {st }}$ August at 9 oclock in the morning, the second day of the court began. Albrecht Truchsess, on behalf of the Estates, requested the questioning of Bartholomew Richau. When it happened, Enoch Baumgartner read his testimony. Richau testified that he had heard from Funck that the Duke and the young Duke wanted to leave the country. When Richau asked, "why does the Duke do this", Funck replied that he has no faithful subjects in the country. Richau was supposed to oppose it. Horst was supposed to be a witness of this conversation, but if he heard it, he could not confirm. Horst reacted to this and took the floor asking to be excluded from the prosecution. Then Albrecht Truchsses spoke on behalf of the Estates, accusing Funck and Horst of jeopardising the health and life of the Duke on this journey. They also put the young Duke, who would have been left without a country and its subjects, in danger. Finally, for the Polish Crown, it would be a display of swagger and recklessness. The Estates therefore asked that the defendants be arrested. Troubled by fears, Richau took the floor and asked to be defended against the evil people because of his true statements. Then A. Truchsess attacked Horst. He said that Horst wanted to get away with it, that he was just a silent witness, but there is a proverb: "qui tacet consentire videtur"- - whoever remains silent, has the same opinion. Anyway, they should ask Richau what Horst said to Funck. Then Richau went to a new hearing and testified there. He had to say everything, so the events were as follows: when Richau found out that the trabants had been ordered to prepare for the road, he asked who advised that, since he knew that the Duke had faithful subjects. Then Horst was supposed to say: "I think he should leave them, they are asking him to leave; for example, they place young men like the one who came before us to guard the Duke. Because the subjects are not obedient and faithful, especially citizens of Knipawa, the Duke must go to foreign places and wait until they become obedient." After the announcement of this testimony, Horst spoke. He testified that it was not true that he had urged the Duke on this journey, but that the Duke himself was willing to undertake it of his own free will, because of the unjust accusation of him by the Estates of the Royal Majesty. That is why he was supposed to go to Poland. The Duke had been thinking about this journey for some time, which can be confirmed by chief steward Erbruchsses and Dr. Jonas, and he was opposed to this journey for fear of the Duke's health. That is why including him among the disbelievers was a slander. That is what Richau is, who takes his nonsense to the council. Horst recommended him to the Duke as his counsellor, and that was his gratitude now.

Funck stated a similar version. He testified that he had never advised the Duke on any travels in his entire life. As for Richau's testimony, it was actually as follows: On Wednesday, August 28, after receiving the lawsuit of the royal com- 
missioners, he learned that the trabants had been ordered to prepare for the road, Funck went to the Duke and asked: "where shall I remain a faithful servant?" The Duke replied briefly, "You are supposed to be with me." Then he noticed that there was such a popular proverb: "You can not deny any master any of your travels because they are going behind or in front of you anyway." And that was all he did. However, when he left the office, going to the building, because of his thirst, Richau approached him and asked: "Does my lord want to leave?" That was when Funck said: "Yes." That was when Richau was supposed to say: "My Lord Duke, help to prevent this, for God's sake, so that he does not make this journey any more effective," and he continued to ask: "What are the reasons for this?" To this Funck was to answer: "My Lord in confession complained to me that he did not have faithful subjects in the country, but these were the words of the Duke, not mine." - Funck said. At that time, he was to dissuade the Duke from the journey, noting that there were many good subjects beside the evil ones. Finally, he concluded that unius testimonium nullum testimonium (a single testimony is not a testimony), also in civil matters, let alone in criminal matters. With two or three witnesses, it is possible to establish the truth. Horst spoke in a similar way, drawing attention to the volatility of Richau's testimony. There was a break, after which the Estates expressed their opinion on the matter. According to them, the defendants are more than suspicious. Only yesterday, Horst claimed he knew nothing, but now he admits he was there. You can see from this that they were both advisors on this journey. Anyway, it is known that the Duke because of his age would not have taken up this journey out of his own will. Richau's testimonies are strong enough because everything agrees with his testimony, i.e. the carts were prepared for the journey, the trabants were dressed. The Estates considered that Richau's testimony is sufficient to torture the defendants. As for Funck, too, because he is a theologian, so he should know that he must not talk about what was entrusted to him in confession. Albrecht Truchsses also protested against Funck for calling him a "guide" of the Estates, but in reality he is only a performer of the will of the Estates.

When Funck noticed that the mayor of Knipawa, Johann von Lohe, was whispering something to Albrecht Truchsses, he said that he met with not only the ingratitude of Richau, but also the ingratitude of the mayor, whom he restored when the Duke expelled him from the country and added that ingratitude would never go unpunished. Funck also denied that he would announce a secret confession. He knew that whoever announces a secret confession must have a tree placed between two houses across the street and be hanged on it. Finally, Albrecht Truchsess asked on behalf of the Estates that this whole matter be investigated in detail. The court proceedings were postponed until Monday due to lunchtime and fatigue. In addi- 
tion, the Duke probably wanted to think about how to proceed on Sunday with his council ${ }^{109}$. The defendants swore an oath to appear for a fixed period and Richau appealed once again to be protected.

On Sunday, September 1, at the departure of Peter Cäsar, the Saxon starost from Leipzig, the guards noticed that he was riding Steinbach's horses and wagon. It was suspected that Steinbach was supposed to be there, too. So the wagon was stopped and Cäsar returned to the inn. Later it turned out that Steinbach gave horses and a cart to Peter Cäsar with an order to leave for Elbląg. However, the sources do not say whether Steinbach himself was to escape at that time. Also on that day, the Duke informed the Commissioners that the trial was being postponed until Tuesday, 3 September.

On Monday, 2 September, the Commissioners were invited to the Neuhausen bestiary for hunting. Even dinner was already prepared. However, the Commissioners refused to accept this invitation because of "their own concerns".

Meanwhile, on Tuesday, 3 September, the Duke announced to the Commissioners that he wanted to postpone the proceedings of the Duke's court until the following day. This postponement has upset the commissioners a lot. They asked to tell the Duke that they saw the new councillors advising the Duke to take these matters as far away as possible. They demanded that the Duke distance himself from the new counsellors and proceed to trial against them. On that day, the City Hall hosted a meeting of the Estates with the councillors, where complaints against the new councillors were examined, letters and writings concerning the crippling practices of the new councillors were read. At night Peter Cäsar was asked to leave Königsberg.

The next day, on Wednesday, 4 September, the Duke, for some other reason (most often he explained the delay with poor health, sleepless night, etc.), asked the commissioners to postpone the court for one day. That ultimately made the Commissioners impatient, because for two weeks now they were sitting here and did nothing, they have not completed a single point of instruction. So they demanded to hear from the Duke this afternoon. The Duke did not accept them personally, but they were interviewed by chief steward Erbtruchsess and Dr. Jonas. There were Estates, too. Dr. Jonas, on behalf of the Duke, asked them not to give him any new worries, it is enough that the Estates have already done so. Jan Kostka replied to this: "They see that all this comes from those scoundrels who sit at the Duke's side day and night and incite him to do so. They must be thus arrested. They (the commissioners) are here to fix evil. The Royal Majesty - and here he showed the royal letter - wonders why the negotiations go so slow. Albrecht Truchsess spoke on

${ }^{109}$ DR, p. LXXIX. 
behalf of the Estates and asked to take back the castle and armoury keys from the new councillors, because they could do a lot of bad things. He further suggested that the Duke should disband the body guard because of huge costs and that the suspect Windeysen should be detained. The speech of A. Truchsess was very bold and entering into the powers of a Duke. He proposed that during the Landtag, the Estates should guard the Duke. The Commissioners have agreed to this! Colonels Wolff Kreytzen ${ }^{110}$ and Andreas Packmohr ${ }^{111}$ were to guard the castle and the armoury and make sure that the defendants did not escape. When the Duke defied them, the tactics of the commissioners was becoming very interesting - they used drastic means, and these somehow helped. That was the case with the lawsuit, and now that was the case with the delay of the trial.

All this was passed to Duke Chancellor Kreytzen and Dr. Jonas. The Duke's answer was as follows: 1 . He does not want to dismiss the new counsellors, but the next morning will bring them to justice, so there was a concession here. 2. He will not dissolve the Colonial Guard because he needs it, he does not want it from the Estates. 3. As for the keys, he told burgrave Fasolt to take them away from Funck.

After this answer, the commissioners and the Estates agreed on guarding the castle. For this purpose, among others, 50 archers were appointed from the craftsmen of the Old Town, who were to guard the castle in addition to the commissioners' service. At 7 o'clock in the early evening, the army, accompanied by drums and pipes, moved to the castle. A crowd of townspeople walked with the army. However, the gates were closed, and Dukely soldiers stood behind. Both sides were already armed against each other. It was a brutal pressure on the Duke. The whole society (communitas) of Königsberg was involved in the strife. The situation was dangerous, so the Duke's statement of 5 September to the cities and nobility was conciliatory, although firm. The Duke thanked the Estates for their guarding (!) but indicated that he did not want them to continue to do so. Archers standing at the gates and at the entrance to the castle should be removed immediately, they should be dissolved altogether. Also the guard on the Pregola was to be removed. The Duke heard that the archers were to forcibly arrest the defendants. The Estates

${ }^{110}$ Wolff Kreytzen, the cousin of chief councillors. Came from Saxony as a wealthy man. In 1539, he was appointed captain of the Duke's infantry, later was promoted to colonel. In 1540, received Ostróda (Osterode) Starosty. During the "Nut War" (wojna orzechowa) in 1563, together with Colonel Andreas v. Packmohr commanded the Duke's army and together with him negotiated with the Wobeser and the Reiters in order to make amends for them in September and October of 1566. In 1570 he was sent together with Dr. Christoph Jonas at the Reich Lantdag in Spira. In 1577 he was resigned in a gracious form (HB, p. 241).

111 Andras Packmohr was a descendant of old Prussian nobility. From 1554 he was a Dukely colonel, commanded the Dukely army in 1563 during the "Nut war" and in 1566 he negotiated with Wobeser's reiters to regulate their pay. He was often used for diplomatic missions, and on May 27, 1566, he was given a 17-lane property by the Duke in the Kętrzyn (Rastenburg) Starosty. He is still found in sources in 1585 (HB, p. 110, footnote 1, p. 114, footnote 1 and G.A. Ausgestorbene Preussischer Adel der Provinz Preussen, v. VI, p. IV; J. Siebmachers, Grosses und allgemeines Wappenbuch, Nürnberg 1874, p. 56). 
answered to this: they will remove the guard if the Duke wishes, but it is puzzling that he prefers to be guarded by strangers, and not by his subjects. In this way, malicious people use it to claim that the Duke has no faithful subjects. As for the archers, they have to be kept for the sake of the city's security. As for the kidnapping (imprisonment) of new counsellors, they do not want it at all, although it should have happened long ago via legal means. Besides, they want to keep watch on the Pregola. As far as chains are concerned, they are made against the arriving reiters who want to enter the city violently, and the Duke ordered them to stay out of it. Finally, the Estates declared that they wanted to prepare cross chains that would close the streets of the cities day and night. In this way, yesterday's incident would be prevented, although both sides remained in office on other issues.

On that day, the commissioners had an audience with the Duke, because the court did not continue its activity. The Duke told the commissioners that he had given new counsellors leave and passports. Johann Schnell has already prepared himself for the journey. The Duke asked that they be allowed to leave freely. The unpleasantly surprised Commissioners replied that this could not happen, first they had to clear themselves of hard charges and then set off on the road. You can see from this that the Duke, devastated by the attitude of the Estates and commissioners, somehow wanted to save his "new" advisors. On that day, too, the Commissioners learned about the so called Klag-Libell complaints book being prepared by the Estates.

The next day, September 6th, Schnell was captured. Between 3 and 4 oclock in the morning, he went on foot to a carter, gave him 2 thalers and asked to take him to Neuhausen. The carter, however, revealed this fact to the citizens of the Old Town. The archers sent brought Schnell back to Königsberg. Here he was placed in the empty basement of the Old Town Hall. However, the commissioners ordered him to be taken to Knipawa, where he was chained up and placed in the Blue Tower. When the Duke found out about this, he asked to send him back to the castle, to which the commissioners replied that since the Duke had granted him a leave and passport, he was no longer a servant to the Duke. Besides, the Estates do not want to hurt him, they just want to subject him to the law.

This is where we conclude the description of the second period of the Landtag. It fills the period of the Landtag's activity connected with the arrival of commissioners until the Estates appear in the complaint against new state advisers, the so called Klag-Libell. The joint action of the commissioners and the Estates led the new advisers to a lawsuit against on 28 August, but the Duke's contraction and his taking over of the initiative led to the delay and court against the new advisers was held on 30 August, which in any case was in line with the commissioners' intentions. Then the first 6 days of September the Duke postponed the court session, 
on the 5 of September he set free the "new" counsellors and wanted to send them abroad, and on the 6 of September, because of the escape, the first defendant was set in the tower. In addition to a general look at the history of the Landtag over the past two weeks, attention should be drawn to the role of the Estates which, although they have generally and officially acted in solidarity, a lack of unity might be felt, probably due to fears of future repressions by Duke. This was particularly evident when the Duke took the initiative and ordered the court, and the lawsuits of the Commissioners seemed to have lost their power. It was then that the Commissioners had to mobilise the Estates to show more courage. Finally, one should pay attention to the attitude of the whole communitas of Königsberg to the Duke's party expressed in the joint visit to the castle on September 4. This period finally crystallized three political camps: the Duke's (new councillors), the chief councillors (party of the middle) and the state. The attacking side was already the Estates supported by the Commissioners. However, the Estates tried to make the Commissioners official and therefore did not suggest what means they should use against the new counsellors, but continued to make new accusations. The Estates did not want to be a judge in the court process and issue a verdict though. They preferred it to be the responsibility of the Commissioners.

\section{The third period. Since the submission of "Klag-Libell" (indictment book)} by the Estates until the first decree. (7 September 1566 to 4 October 1566) ) $^{112}$ The third period of the Landtag is characterised by the activity of commissioners to restore order in the country. This activity will culminate in the decree of 4 October.

Similarly, the Estates will fight for privileges following a state complaint Klag-Libell. Outside, however, all this takes the form of a court case against the new counsellors.

This is the history of this period.

On Saturday, September 7, 1566, the court was reopened. Both Dukes, commissioners, judges, the Estates and three defendants were present: Funck, Horst, and Steinbach.

First, Horst protested that he had no dispute with the Estates, but only with Bartholomew Richau. He pointed out that he served not the Estates, but the Duke, so it was the Duke to punish him, not the Estates.

The Estates then lodged a written complaint, the so-called Klag-Libell ${ }^{113}$ and asked for its reading. This duty has fallen on Gaspar Dargitz. What was the state complaint about?

112 Source material was taken from AB, pp. 344-373 and pp. 471-483. News from other sources are provided with footnotes.

113 AB v. III, pp. 347-358. 
It was filed by Matthias Bögner as the prosecutor representing the applicant, i.e. the Estates, against the destroyers of public peace: Johann Funck, Matthias Horst, Johann Schnell and Steinbach, and their supporters. The prosecutor reserved the right to shorten or enlarge the complaint if necessary. He further pointed out that it was not for the humiliation of the Duke, but vice versa, for his fame, to restore order to the country.

The complaint covered two points:

1. the defendants wanted to change the well-designed church and state system, 2. the defendants led the Duke into financial poverty by getting rich themselves. Within these two main accusations, Klag-Libell listed the following specific accusations.

Point I of Klag-Libell:

a) church affairs:

Funck was a supporter of a heretic, Andreas Osiander ${ }^{114}$, and forcibly introduced his teachings. He removed opponents from the church and state offices. In place of the old church order (1544), he introduced a new order (1558), without the knowledge of the Estates. This order was "highly malicious about the sacrament of baptism". Opponents of the new order were persecuted and displaced from the country.

Funck introduced a reckless man, Johann Aurifaber ${ }^{115}$ to the office of the President of the Sambian bishopric, and Horst introduced a similar man to Pomezania, Matthäus Rösler ${ }^{116}$.

b) state affairs:

The defendants joined Paul Skalich and acted with all their might to overthrow the country's general state order. To achieve this, they accused the old coun-

114 Andreas Osiander (1482-1552), a reformer and Lutheran theologian, however, preached slightly different theses than Martin Luther about the doctrine of justification (salvation) and the doctrine of the divine and human nature of Christ. In the first one, he paid more attention to penance and less to the possession of faith. In the latter, unlike Luther, he separated the two natures in Jesus Christ (divine and human). He came to Prussia in 1549 and became a preacher in a church in the Old Town. Under his influence, the organization of the Church in the duchy was also changed and the bishopric was not staffed with the introduction of a consistory (see Die Religion in Geschichte und Gegenwart, Bd, IV, Tübingen 1960, pp. 1730-1731; G. Seebas, Der reformatorische Werk des Andreas Osiander, Nürnberg 1967; M. Stupperich, Osiander in Preussen:1549-1552, Berlin 1973).

${ }^{115}$ Johann Aurifaber (1517-1568), brother of Andreas, son-in-law of Andreas Osiander and the leader of his party. He also studied in Wittenberg. He was a professor of theology in Rostock, then in 1554 in Königsberg. As a supporter of Melanchthon, he tried to settle the Osiander dispute. He was elected the president of the Sambian bishopric. He also briefly administered the Pomezanian bishopric (Ch. Hartknoch, Preussische Kirchen-Historia, Frankfurt-Danzig 1686, p. 169). In 1566 he left for Wrocław, where he took over the parish of St. Elizabeth. (Cf. Die Religion in Geschichte.und Gegenwart, III ed., vol. I, Tübingen 1957, pp. 751-752).

116 Matthäus Rösler, doctor and professor of medicine, Rostock syndicate. He was in Königsberg for a few months. Vice President of the Sambian bishopric. Perhaps he also replaced Johann Aurifaber in his duties in the Pomezanian bishopric (A.R.. Gebser, E.A. Hagen, Geschichte der Domkirche zu Königsberg, Königsberg 1835, p. 381) 
sellors of infidelity to the Duke, told him that they wanted to declare disobedience to the Duke, and even that they wanted to deprive the Duke of his office and close him down, and that the young master would not want to be recognized, but would put one of their own on the throne. They have done irreparable damage with all these things to the old counsellors. For this reason the old counsellors were dismissed or vacated. In this way, new strangers were called in to replace the old ones. And so Laurentius Kirchoff of Rostock became Chancellor.

The defendants set up a secret registry, from which many unjust orders, mandates and unjust sentences emerged. There has even been a confiscation of property. These scriptures were sometimes sealed with a great seal, but neither the old counsellors nor the secretaries knew their contents. Many letters were written without the Duke's knowledge. However, when the Duke found out about it, he forbade any further such action with a Kreutzburg mandate. In this office a ticket was printed, in which the Duke urged the Estates to take care of Paul Skalich and the Duke gave him power. Here, Skalich was helped to work out the paszkvili against the emperor, which were printed. Schnell was supposed to be their author. In turn Steinbach was to disseminate one of the books by Skalich entitled "Justitia" without permission in the country ${ }^{117}$. Here, a document was drawn up about the recruitment of 1000 reiters of Colonel Wobeser, supposedly with the consent of the Estates, which is not true. In addition, a bond was issued which entitles Wobeser to "repress" the goods in case of failing to pay his wages.

How miserable are the defendants, if they were able to expose the country and its inhabitants to the robbery of foreign troops - it was written in Klag-Libell. The governorship was also established, and finally Dr. Kirchoff changed the old Duke's will (from 1555). ${ }^{118}$

Point II of Klag Libell:

A year ago the defendants were ragged, today they are dressed in rich silk robes with gold chains. The Duke has equipped them with great wealth and properties. Meanwhile, they continued to squander state pennies. They persuaded the Duke to lend 12,000 thalers to the Baden margrave. Sixteen thousand thalers were sent to Skalich in France, allegedly for the marriage of young Duke Albrecht Frederick. They gave away lands, money, wood, grain, amber, made records and contracts. They also gave diplomas and nominations to strangers, so that they might become faithful citizens and servants of the new orders. This extravagance caused that there

\footnotetext{
117 AdamVetulanl (Władztwo Polski, p. 173, footnote 32) presumes that the author of this print was Steinbach. Sources, however, admit that Skalich was the author, Steinbach was supposed to be only a distributor.

${ }_{118}$ Regarding father's Albrecht last wills see: A. Bues, I. Kąkolewski, Die Testamente Herzog Albrechts von Preussen aus den sechziger Jahren des 16. Jahrhunderts, Wiesbaden 1999.
} 
were not enough funds in the camera to cover the most important, current state expenses. For this reason, it was necessary to take money from the nobility's cash registers in order to release the castles from the pledges. Finally, they persuaded the Duke to impose an unacceptable and uncollectible tax. A lot of money went to Wobeser, too. Finally, in connection with the recruitment, the way through the spit to the interior of the country was revealed, which could be dangerous for Prussia and Poland.

Finally, Klag-Libell demanded to extract the whole truth from the defendants and asked the Duke as a judge to punish the guilty.

That was the content of the complaint.

After reading it, Horst spoke out protesting that he did not want to deal with the Estates, but only with Richau. He asked for Richau to be arrested because he wanted to go to trial with him. As for Klag-Libell, it mixed spiritual and secular matters. However, he asked for a copy of the indictment and time to prepare a justification. At that time, the Estates stated that since the complaint was widely known, the accused could not be given a long period of time. The Commissioners were also of this opinion. Finally, the Estates demanded that the defendants be arrested because they could break their oath to appear before the court, as Schnell's escape proved. Horst then spoke and said that a period of four weeks would be the most appropriate time to reply. He also declared that he would not break his oath. At that time, after the meeting, the Duke's order was published. The accused were given three nights and three days to prepare their response to the charges brought against them by the Estates. The defendants should only swear by hand that they will be here at the appointed time. Only Schnell is to remain in prison. The defendants took the oath of allegiance with their hands and the meeting was adjourned.

On Sunday, September 8, 1566, the Commissioners were in the bestiary, and on September 9, 1566 Schnell gave testimony. He talked a lot, especially about Horst. On September 10, 1566, another court session was held. The three defendants responded to the Klag-Libell accusations, of course completely denying them and complaining about the short time they had to prepare their answers. The answers were then read out: Kasper Dargitz read Funck's letter, Enoch Baumgartner - Horst's and court writer - Steinbach's ${ }^{119}$. We do not know the contents of these testimonies except for Steinbach's testimony ${ }^{120}$. Steinbach denied all the charges in Klag-Libell. He said that when he came here, he found such order and did not change it. He knows nothing about governorship, repression, change of will or the fact that Horst appointed Matthäus Rösler, the President of the Pomezanian Bish-

119 Pawiński, DR, p. 67, gives only the titles of these documents, because when printing the diary of the activities of Polish commissioners in the Duchy of Prussia in the years 1566-1568 he left some parties.

${ }_{120}$ APO V/3-6, p. 54-69. 
opric, without the consent of the nobility. As for financial matters, he did not make any financial problems for the Duke, nor did he get rich here. He only received 60 carts of tree. He did not do the transcripts either. There was a short break in the court proceedings for a separate state meeting. After the break, Matthias Bögner spoke on behalf of the Estates. He declared that the Estates did not abandon the previous complaint (Richau case), but wanted it to be dealt together with the whole of Klag-Libell. He further added that it was illegal and godless for the defendants to blame the Duke. Finally, he pointed out that Schnell's testimony was directed against his companions and that the Estates were therefore asking for their information. "In any case," Bögner continued, "these things are notorious, even children know about them on the street and one could say that both trees and street stones could talk about them." In conclusion, Bögner demanded the arrest of the defendants. Horst replied that Bögner was a street preacher and that is how he was known to the children, and he is a master of tricks and that is why he wants at least the trees and street stones to talk about him well. This statement was intended to discredit state attorney Bögner.

The commissioners through Jan Kostka reported that since the Estates wanted to publish the testimony of Johann Schnell, which he voluntarily gave in the presence of judges and signed in the prison in Modra Tower, they agreed with this request. The Duke was given this testimony at the time. He immediately took the letter in his hand and watched it carefully, checking whether it was Schnell's hand, and when he recognized it, he reluctantly said: "What does this unhappy liar want?" The letter was then read out. We do not know its content any closer ${ }^{121}$. All we know is that it contained allegations against Horst and Funck. Therefore, they immediately began to defend themselves, trying to reject these charges. Bögner has once again demanded the arrest of the defendants, since they were changing their testimony and the court was pressing new charges against them. Horst strongly opposed, asking the Duke to stand up for him, because he had always faithfully advised him and sought the truth. If the Duke's testimony was not recognized, he would know that even if the angel comes down from heaven, they would not recognize anything. The Duke was silent ${ }^{122}$. Why? We shall see about that. Horst then said that he was surprised that they put so much pressure on the Duke, that in other countries Dukes demand obedience from their subjects, and here it is the other way around. Then a long-restrained anger broke out in the Duke's eyes, he became quite "brown" on his face, hit the table and said: 'I do not know, I am not guilty, you villain,' he pointed to Bögner, 'leave me alone, or I will meet you!'. This Duke’s statement is very

${ }^{121}$ Pawiński, DR, p. 68, gives only the title of the document.

${ }^{122}$ Pawiński DR, p. LXXXVIII. 
revealing. After all, he was not obliged to report to his subjects. The Duke did not want to be the "president of the noble republic", but a real or even absolutizing ruler. He was therefore not fit to defend Horst in order to benefit from the Estates. The attack of anger of the 76-year-old Duke Albrecht could have resulted from the fact that the indictment of Klag-Libell prepared by Matthias Bögner included a motion for trial containing a request for the testimony of the Duke under oath ${ }^{123}$.

Then Dr. Jonas read the Duke's decree that the defendants should take the oath by hand and the court proceedings should be concluded on that day. The Commissioners responded to the Duke's harsh words with a firm response.

On Wednesday, September $11^{\text {th }}$, the commissioners came to the castle. The Duke did not accept them personally, but only by his counsellors. The commissioners asked for the Duke to be informed that they knew well what the new councillors were up to. They wanted to persuade the Duke to take all the blame, which he was doing so far. That was why they asked the Duke if he was taking the responsibility for all these matters or not. If he took it, he would have to answer to the Royal Majesty and the Crown of Poland, because all these matters were against the treaties. If, however, the Duke did not take it (which he did not need to do at all), he would have to distance himself from of the bullies - the new counsellors. The Duke promised to give an answer on another day.

The next day, the peers' court was ordered for Elijah Kanitz. By making a concession to Kanitz, the Duke wanted to shake up the persistence of the Commissioners in some way and, under the old tactics, to delay resolving the cases. The court was composed of 12 persons, of whom 11 persons are named by the Landtag's diary. They were: Johann Jacob Erbruchsses - chief steward, Jonas von Eulenburg, Jacob Schwerin - chief steward of the young Duke, Nicolai Sparwein ${ }^{124}$ - starost of Tapiawa, Frederick Aulack ${ }^{125}$ - starost of Nidzica, Kasper Lehndorff ${ }^{126}$ - starost of Iława, Georg Rauter - starost of Jorgenburg (Georgenburg), Georg Hohendorff ${ }^{127}$ - state judge, Gröben ${ }^{128}$, Johann Truchsses ${ }^{129}$ and Taubenheim ${ }^{130}$. The Chancellor took an oath from them and Elias Kanitz lodged his complaint against the Duke. It was accepted by the Duke's attorney, Sigmund Kerstendorff-Kierstanowski, the

${ }^{123}$ J. Małłek, Proces kryminalny, p. 204.

${ }^{124}$ Nicolai Sparwein - starost of Węgorzewo, and since 15 November 1565 starost of Tapiawa. (HB, p. 200, footnote 4 and p.352)

${ }^{125}$ Frederick Aulack - due to his support for the Calvinist religion, had to resign from office in the principality in 1566 (HB, p. 17, footnote 4).

${ }^{126}$ Kasper Lendorff - administered the Bartoszyce district in the 50s of the $16^{\text {th }}$ century and in the years 1574-1577, was also the chief steward of Duke Albrecht Frederick in the years 1567-1574 (HB, p. 251 and 344).

${ }^{127}$ Georg Hohendorff - starost of Kętrzyn in 1559-1561 and probably Szestno (Ger. Sehesten) in 15621563 (HB, p. 41, footnote 4 and p. 350).

${ }_{128}$ Gröben - probably Georg v. Gröben, see footnote 17

${ }^{129}$ Johann Truchsess - no data.

${ }^{130}$ Taubenheim - no data. 
Mayor of Szaki, who asked for a 6-week deadline for his reply. However, the Court gave him 8 days to prepare his reply.

On Friday, 13 September, Frederick Kanitz ${ }^{131}$ was in prison to visit Schnell. Schnell asked him to forgive him for what had happened to him and his brother Elijah and to ask him to intercede with the commissioners and the Estates. On that day, Jan Dymitr Solikowski, the secretary of the commissioners, returned with several letters: to the Duke ${ }^{132}$, commissioners ${ }^{133}$, old Dukely advisors ${ }^{134,135}$, castle starosts, and finally Wobeser ${ }^{136}$.

The King, having learned of the Duke's resistance, sharply admonished the Duke in a letter of ingratitude. "Since it came to the royal ears that Duke Johann Albrecht of Mecklenburg, who intends to come to the Duchy to take possession of it, is to be appointed Prussian governor against King's will, he asks Albrecht to admonish his son-in-law and refrain from interfering in the affairs of the Polish sovereignty over the Prussian fief" 137 . So the "constantly late" Mecklenburger wanted to play his part now. He was a weak politician or he was badly informed about the situation in Ducal Prussia, if he wanted to come there by that time. Besides, I have already presented the matter of the so-called coup détat based on Mecklenburger and I will further supplement it with the testimonies of the defendants. It should be added here that on 13 September the commissioners learned from Schnell that recently in the castle there was talk about offering Klaipeda to Pelikan ${ }^{138}$, the rotamaster of the Duke of Mecklenburg. Undoubtedly, the uniform attitude of the Estates and commissioners and the crown behind them did not give Mecklenburger any hope for success in this situation in the Duchy. However, the Duke of Mecklenburg, already known for his adventures in Livonia, could have caused new disorders here.

In a letter to Duke Albrecht, King Sigismund Augustus further wrote that he did not need Wobeser's mercenaries in Livonia anymore, so he should dissolve them. In his letter to the Commissioners, he told them to stick strictly to the in-

${ }^{131}$ Frederick Kanitz - hereditary settled in Dallwitz, was a fief of the Bishop of Meissen. As a result of the unpleasant consequences of his love relationship with a Leipzig townswoman, he was expelled from the country and after long journeys in 1557 he entered the service of Duke Albrecht. He soon became Duke's councillor and a camera councillor, and in 1563 he became the head of the camera (Oberkämmerer). Initially, he was in friendship with Skalich. When Elijah's brother fell into the disfavor of Albrecht, Frederick was dismissed in March 1566. In November 1566, he was restored to the Duke's grace (see HB, pp. 239-240).

${ }^{132}$ DR., pp. 74-75.

133 Ibidem, pp.75-76.

134 Ibidem, pp.77-78.

135 Ibidem, pp. 78-79.

136 Ibidem, p. 79.

${ }^{137}$ Pawiński DR, p. XC i p. 75. Ceterum cum turbis istis tragicis se [suam - ?] personam immisceat illustris Dukeps Joannes Megapolitanus dux, qui nobis invitis governor constitutus feudi nostri passessionem apprehendere velle dicitur, postulamus quoque ab Illustrate Vestra, ut literis suis principem eundem, generum suum, dehortetur, ne de tali gubernatione suscipiendia quidem cogitet, multo minus se se in Prussia illius spe conferat'.

138 Pelikan - no data available 
structions and to use their power as far as possible. In a letter to the old council, the King urged them to help the commissioners with their work of repairing the state. To starosts, he ordered them to guard the castles well and not to give them back to anyone. Finally, he wrote to Wobeser to dissolve the reiters and give away the records by which he had the right to repress the goods. The royal letters had a decisive influence on the further course of negotiations with the Duke, who became more agreeable to the wishes of the commissioners.

On that day, 13 September, the Commissioners negotiated with the Duke through advisers. At the end of the negotiations, probably under pressure he had received from the royal letter, the Duke replied to the commissioners, through Chancellor Erbruchsessa and Dr Jonas that he wanted to hand the accused over to the commissioners so that they could escort them to Poland, to Malbork, where they would be brought to justice ${ }^{139}$. At the time, the Commissioners said that they had to ask the Estates about this, but the Estates did not want to allow it and demanded that the defendants be brought to trial here on the ground. At that time, the commissioners also rejected the Duke's project. In any case, the scenario of sending the defendants back to Poland, where, no doubt, a lesser sentence would be applied, fell as a result of resistance from the Estates. In this way, the commissioners were somehow justified against accusations of wrongfully causing the death of three new Dukely advisors in later history. I will deal with the issue of whether the sentence was fair or unfair at the end of my work.

Under the same date, on September $13^{\text {th }}$, Christoph Rauter appeared at the Landtag $^{140}$. He appealed to the memory of the Members of Parliament that in the previous Landtag the Duke ordered the purchase of mortgaged castles also from state money. When the Duke demanded from him the entrusted money, and he did not want to give it, he had to hide under the threat of losing his life. Now he is protesting against it and is asking the Estates to stand up for him, so that something similar does not happen to him in the future. At the end he handed the Estates the keys to the "national Polish caste", i.e. the state cash register.

The next day, September $14^{\text {th }}$, on Sunday at 2 oclock in the afternoon, a joint meeting was held, attended by both Dukes and councillors, commissioners, Estates and the three defendants. Dr. Jonas presented the Duke's verdict in the case of the defendants, and Kasper Dargitz read it. What did the verdict say? The Duke stated

139 Pawiński, DR, p. XCI.

${ }^{140}$ Georg v. Rauther - in the years 1555-1562 starost of Dąbrówno. He belonged to Natangian’s “cash lords" with its registered office in Kętrzyn. The Duke, when he was short of money, turned to the state cash registers and e.g. 20 X 1565, with a receipt from the Sambian cash register, he took 14,333 thalers and 11 groszes, on 17 February 1566, 3,000 Marks, July 20, 1566, 6,734 Marks, 47 shillings. But when the Duke demanded money from the cash lords of Natangia one by one, he received a negative answer. Reuter (Rauther?) escaped in the summer of 1566 from the Duke's anger to Warmia. He died in 1571 (HB, p. 243). 
that, in order to free himself from any suspicion, he was giving up these three accused Commissioners to deal with them legally ${ }^{141}$. At that time, the commissioners handed the Duke the reverse in Latin, in which they assured the Duke that they would defend the accused against harm and lawlessness and that they would act in accordance with the law ${ }^{142}$. Then Bögner, here in the role of the state's attorney, gave the Duke a heartfelt thanks for his sentence. Then the defendants took the floor. Funck hoped that the Commissioners would treat them as Christians, Horst declared that he was innocent, and Steinbach spoke briefly, expressing his solidarity with the statements of the co-defendants.

So the royal letter worked, the Duke gave his favourites to the commissioners. From now on, the situation in the negotiations with the Duke would change completely. The things, although slowly and stubbornly, will move forward.

Meanwhile, at this meeting, chief steward Erbtruchsess and Chancellor Johann Kreytzen made accusations against the new counsellors. These speeches should probably be considered, because - as we accepted above - Truchsses and Kreytzen entered the so-called 'middle party in this dispute. Erbruchsses accused Steinbach of having publicly insulted him six months ago, during his stay at the Duke of Courland, where he appeared as the chief steward of the Mecklenburg Duchess Anna Sophie, the daughter of Duke Albrecht. He has complained to the Duke, but has not yet received justice. However, a few days ago Steinbach asked him to forgive him, and he is now in a difficult situation, so he crossed the matter out, let Christ forgive him. He finally demanded that Steinbach make a public appeal, which also happened. It seems to me that Erbruchsses's speech was supposed to arouse pity among the defendants. This is a clear line of the middle party in this period: the defendants are guilty, but you cannot be a harsh judge against them.

Chancellor Kreytzen attacked Horst that at magrave of Baden's, in the presence of numerous Dukes he was supposed to express his opinion about old counsellors that they were unfaithful people. When it was complained to Duke Albrecht, he sent the matter to the court, but so far they have not received justice. Horst replied that in this case he had a Duke's verdict with a signature and stamp that acquitted him. These accusations were made by his enemies, and now everyone wanted to confront him. He was aware that he came to this unfortunate situation for no other reason than that he served the Duke faithfully, and he is sorry that this is now being talked about. As you can see, Horst had a cut-throat tongue. Anyway, was it not a bit right that the policy oscillating in the direction of absolutism was in accordance with hopes of the Duke? And yet many resolutions went in this direc-

${ }^{141}$ DR, p. 81, there's the final part of the sentence.

142 DR, p. 81. 
tion, by violating the privileges of the nobility, mainly the "Regimentsnottel Act" of 1542. This state policy was following Duke's expectations, but did not have a proper social or economic base, so it could not give results.

In response, Kreytzen pointed out that he did not want to have anything to do with Horst, but he wanted to know from the Duke where he could direct these complaints. The party of the middle or chief advisors has securitized itself in such a way that it does not appear together with the accusations of the state party, which would cause dissatisfaction of the Duke. When Horst "came out of the hands of the Duke", one could not fail to take care of his own interests - that is, to present the old charges officially. Undoubtedly, it was also about the return of other old counsellors to their positions, apart from the newly appointed Chancellor Erbtruchsess and Chancellor Kreytzen. Finally, the Duke, explaining himself by shortness of time (because at 5 o'clock the accused were to appear at the governor's inn), did not give a reply to Kreytzen, but promised to present it at the first opportunity ${ }^{143}$. Then the defendants swore an oath to appear at a specified time, and then there was the Duke's farewell. Especially Horst's farewell to the Duke was very sad. Horst cried fearfully and put his head in the Duke's bosom. The Duke also cried. The Duke said goodbye to the governor of Brest, Johann from Służewo, for a particularly long time. The streets that the defendants were to cross were filled with crowds of people. Half an hour after their departure, the defendants were already accused in Knipawa, on Długa Street, in Johann Kesen's house ${ }^{144}$, in the inn of Voivode Jan Służewski. They were then placed in the town hall and guarded closely. It was the first success of the commissioners and the Estates. After a three-week period of activity, it was finally possible to remove the obstacle which was constantly blocking the fulfilment of the instructions by the royal commissioners. The new councillors were imprisoned, and the Duke was separated from their influence. It was possible to start restoring old relations in the country, but first the guilty had to be dealt with. A problem has arisen, what to do with them? To this end, the commissioners turned to the old Dukely councillors for advice ${ }^{145}$. In an interview with chief steward Erbtruchsess and two doctors on 16 September, the commissioners declared that they wanted to continue the trial, because the next day, with the permission of the Duke, they could administer justice ${ }^{146}$. They did not know the laws and customs of the locals, nor would they want to violate them, and they asked the Duke's counsellors to come to tomorrow's court, where they would act as legal counsellors, as guardians of the law. The commissioners have encouraged this in vain. The

\footnotetext{
${ }^{143}$ DR, p. 81, gives 4 o'clock.

144 Kesen - bourgeoisie - no data.

${ }^{145}$ Pawiński, DR, p. XCIII - XCIV.

146 DR, p. 89.
} 
chief advisers evaded trouble and responsibility. On that day, the "Commissioners' court" of the guilty was established. First of all, it should be mentioned that the Commissioners questioned Schnell and Horst at the town hall for five hours. A joint meeting of the State Committee with the Commissioners followed. The Estates stated that it remained on the indictment of the defendants, as "perturbatores reipublicae" and "hostes patriae". They demanded that the case be continued, asked for the documents needed for the trial to be taken out of the Duke's office, and finally demanded that the three defendants be separated. Commissioner Jan Kostka replied that the defendants would still be spending the night together, because the Duke had asked for it. The files needed for the trial would be taken from the castle. Then the defendants were brought in and the trial went on. Albrecht Truchsess stated that the Estates remained on the complaint and demanded that the case file be retrieved from the Duke's office. The defendants also asked for their testimonies to be brought from the Duke's office, as they testify to their innocence. Only Schnell asked that he wanted to respond once again to the complaint, because he had only one night to prepare his response. He also asked for his chains to be removed if the other defendants were not cuffed. To this Mr Kostka replied: qui semel malus, semper praesumitur talis, because he once ran away, now they have to be careful. Schnell replied that he fled not of his own free will, but Horst ordered him to do so in the presence of the Duke. He asked once again that he be freed from chains. He was allowed to take his shackles off his feet and was given a barber to bandage his swollen legs, but the chains on his torso remained.

Finally, on behalf of all the Council's advisers, the Commissioners received a reply on 17 September saying that there is a "throat case" (case of great importance) here, so they cannot take part in it, which they are also not doing under the leadership of the Duke himself $f^{147}$. The Commissioners affected by this excuse stated that they would not take part in the trial themselves, as they would also be inappropriate to take part in a court of law in the event of a throat case. In fact, they only wanted to consult together whether to torture the defendants. As for the future fate of the prisoners, they want to hand them over to the competent court. The counsellors replied that they had heard from their colleagues about a different demand and therefore they had to go back to them first in order to think about the final answer. Chancellor Kreytzen, while leaving, whispered in the ear of the Commissioners a personal opinion to send the accused back to Malbork, thus relieving the Duke's worries and giving him a good disposition for further business. The Commissioners would be happy to agree to this, as they wrote in the diary, as long as the Estates agree to it. Again, the Estates refused and demanded that the case continued. The 
applicant should have been compensated. Finally, on that day (17 September), the chief advisors answered that if the defendants could not be escorted to Malbork, then one should not rush to pass a sentence in order not to irritate the Duke, so that he would be more docile to other matters. They promised themselves that they would take part in further courts as assessors and would have a positive influence on the Duke so that the points contained in the royal instruction to the commissioners could be implemented.

The Commissioners, following the advice of the counsels, suspended the court proceedings ${ }^{148}$. Meanwhile, in the Old Town's Hall, the Landtag discussed the matter of sending the defendants back to Malbork. It was decided that the defendants should remain at the place and should be brought to justice here. The trial should not be prolonged because the defendants may flee.

On that day, the above-mentioned Pelikan, a servant of the Duke of Mecklenburg, swore to the Commissioners that he would not "flee" without their permission $^{149}$. On September 18, the commissioners negotiated with the Duke at the mediation of the Duke's advisors ${ }^{150}$.

On Thursday, 19 September, in the hall of the Council of the Old Town' Hall, councillors, noblemen and townspeople discussed the accusations they wanted to make against the commissioners, so that they could receive a reply from the Duke. A. Pawiński only mentions the titles of those documents, from which it follows that they contained postulates of the Estates regarding the restoration of order in the state ${ }^{151}$. The Estates went to the town hall in Knipawa and with some pressure demanded that the commissioners continue the trial against the defendants. However, the Commissioners, having familiarised themselves with their written complaints, did not agree to the process being conducted immediately and stated that matters should be dealt with in the following order: 1 . To listen carefully to the complaints of the nobility and cities and present them to the Duke, 2. To restore order in the government, 3. To revoke the right to "repressions", 4 . To sentence 4 defendants.

On that day, the Commissioners received a letter from Colonel Paul Wobeser to the effect that he would not dissolve the reiters before the outstanding money had been paid to them by the Duke ${ }^{152}$. He was not going show up personally if he does not get a safe conduct. Only if he received one, he could stand before the Duke and impartial judges and answer. Then he was sued twice again, and the safe conduct was sent to him.

\footnotetext{
148 Pawiński, DR., p. XCIV.

149 Memorial, PTT. p. 779.

150 Memoria, PTT. p. 799.

151 DR, p.93.

${ }^{152}$ Memorial, PTT., p. 799.
} 
The Commissioners, sticking to the plan of their actions, the next day, i.e. on 20 September, went to the Duke, where they discussed with him the articles contained in the complaints of the Estates aimed at restoring order in the state. The Duke, however, did not give the answer, postponing it into Monday ${ }^{153}$. A certain step has been taken towards a better solution, as Joachim v. Borcke ${ }^{154}$, the chief Marshal and Dr. Francis Thegen ${ }^{155}$, the Vice-Chancellor, have been ${ }^{156}$ reinstated in their former office. The case of Dr. Jonas, who had previously also been dismissed, was also discussed, and it was agreed that he should hold his former post ${ }^{157}$.

The case of Elijah Kanitz was also considered in the Peers Court ${ }^{158}$. Duke Sigmund Kerstendorff's lawyer gave a written response to Kanitz's charges. In fact, the answer contained more accusations against Kanitz than excuses for his accusations. And so the Duke accused Kanitz of misinforming the King of Prussian affairs, and as a result he humiliated the Duke in the eyes of the King and acted against him. In response, Kanitz said that what he did was only to maintain the reputation of the Duke and the peace and prosperity of the principality.

Meanwhile, the issue of reiters still remains unresolved, so on Saturday, 21 September, the Duke turned to the Estates with a request for $5000-6000$ thalers to pay for these reiters. With this money colonels Andreas Packmohr and Wolff Kreytzen went to Tylża to Wobeser's reiters, while commissioners went for a horse ride on that day.

On that day, two letters arrived in Polish from the bishop of Warmia, Cardinal Stanisław Hozjusz dated September 21, one addressed to the Commissioners and the other to Jan Kostka ${ }^{159}$.

In his first letter, Hozjusz reported that he had received letters from friends in Königsberg, who were afraid that the commissioners would not leave too soon. The cardinal therefore asks them not to leave there until they have put order in place. In his second letter, he raised the issue of the former burgrave Christoph Kreytzen and Paul Wobeser. The first letter is particularly interesting as we learn about the moods

\footnotetext{
${ }^{153}$ Memorial, PTT., p. 780.

${ }^{154}$ Joachim v. Borcke - (born in the Duchy of Pomerania, $\uparrow 11$ X 1572 Pokarmin), brother of Antoni, the Starost of Pokarmin. He came to Prussia in 1540, and in 1541 he was accepted into the Duke's service. Married to Dorota v. Schlieben. In 1549 the Duke promised him the office for loans. In 1554 he was the starost of Rybaki, in 1556 he received the office of Ełk as a pledge, in 1558 he was a chief marshall . (Altpr. Biogr. Bd. I, p. 71/2) Geschichtsquellen des burg-und schlosgesessenen Geschlechts von Borcke, hrsg. G. Sello, v. III, p. I, Berlin 1907, pp. 766-777.

${ }^{155}$ Franz Thegen - a long-time Dukely councillor, at least in the years 1545-1570. In the spring of 1566 he was dismissed from his office. He died at the end of 1572 (see HB, p. 182, footnote 7 and J. Gallandi, op. cit. p. 608).

156 AB, p. 476.

157 Memorial, PTT, p. 780.

158 Memorial, PTT, p. 780.

159 Letters are printed by Pawiński, DR, pp. 96-98a. for translations into Polish see A. Vetulani, Władztwo polski, pp. 183-187.
} 
prevailing in Königsberg and it also partially explains why the Duke's councillors initially refused to participate in the trial against the three defendants.

On Sunday, 22 September, the Commissioners took part in a baptismal party at the home of Chancellor Johann Jacob Erbuchsses von Waldburg. The old Duke was also present there, with his family, while his favourites waited for the verdict ${ }^{160}$. Immediately on Monday, September $23^{\text {rd }}$, the commissioners demanded a promised response from the Duke on the accusations made by the Estates against the Duke and presented to him by the commissioners on September $20^{\text {th }}$. The Duke once again delayed, promising to give an answer tomorrow ${ }^{161}$. On that day, the defendants were separated late in the evening. They were escorted by the municipal police and Judge Dominic Perbandt ${ }^{162}$ to their destination. That is how they were placed: Horst - in the gate of Długa Street in Knipawa, Steinbach - in Nowa Brama near the cathedral bridge, Funck - in Brama Kowali.

They were chained up there by order of the commissioners. On Tuesday, 24 September, Commissioners interrogated Horst because of a letter from the Estates to the Duke, formerly pledged. Also on that day, a Knights Jury on the case of Elijah Kanitz was held at 8 oclock. Kanitz responded to the Duke's charges. Two members of the court, Dr. Hieronim Rohde ${ }^{163}$ and Dr. Ambrose Lobwasser, the then rector of the university, both lawyers, were negative about Kanitz. Kanitz demanded that they be removed from the court because under the law of fief and knighthood no one can be of any help to anyone in the court. The difficult and unclear German text is to be understood that both doctors were too attached to the Duke to be unbiased. The Kanitz's request was granted and Lobwasser and Rohde left the court. It was then that Kanitz's letter was read out and handed over to Duke's spokesman, Kerstendorff, with an 8-day deadline for his reply. This case was finally successful for Kanitz ${ }^{164}$. The Duke was to give him 10,000 thalers to settle his claims, 2000 thalers in a good coin and 8,000 thalers in a forma of a pledge in Kętrzyn county, to which the Estates did not want to agree, because Kanitz is not an indygenat. It is worth noting that the nobility remained firmly committed to the privileges of the indygenat since they did not want to make this concession in this dispute even for Elijah Kanitz, who was so merited for the nobility.

On Wednesday, September $25^{\text {th }}$, the Landtag again held its sessions in the Old Town Hall in the presence of Commissioners. Albrecht Truchsess had informed the

\footnotetext{
${ }^{160}$ Memorial, PTT, p. 780. C. A. Hase, op. cit., p. 354.

${ }_{161}$ Memorial, PTT, p. 780.

162 Dominick Perbandt (1507 - 4 II 1602). In 1566, he was a judge, then mayor of Knipawa. He got married in 1547 with Anna, daughter of Joachim Cniper, mayor of Knipawa, widow of councillor Andreas Krause. (J. Gal-

${ }^{163}$ Hieronim Rohde - no data.

164 The author of Acta Borussica, p. 478 in footnote, gives these messages concerning the end of Elijah
} landi, op. cit. p. 217). Kanitz's case. 
House that the Duke had replied to their objections. He received this letter from the Commissioners. In the letter, the Duke assured that he would try to remedy their problems and complaints, but did not state how he would do so. The Estates therefore asked commissioners to ask the Duke to state what measures he wanted to take to remove the evil in the country. At the Landtag on that day Antonius v. Borcke ${ }^{165}$, the starost of Pokarmin, spoke. He stated that because of the order that the starosts of the main starosties should be Prussians by birth, and he is a Pomeranian, he is forced to ask for resignation. At the same time, he wished the Estates a long stay within their national freedoms and good order. Albrecht Truchsess replied that the whole state was as satisfied with him as possible and that everyone wanted him to remain in his office and in his country. In this case, they made exceptions, while for Elijah Kanitz, they did not. What was the reason for this? We cannot give a conclusive answer.

On the same day, the Duke's councillors negotiated with the commissioners on disputes between the Duke and the Estates. Finally, the Duke and the Estates were found to be far from agreeable, and so they demanded that the Estates shoutd come to the castle the next day to discuss these matters in greater detail ${ }^{166}$. On Thursday, September 26th, a meeting took place at the castle; the meeting was attended by: commissioners, Duke's councillors as follows: chief steward Erbtruchsess, Jonas von Eulenburg, Jacob Schwerin, Dr Christoph Jonas, Sigmund v. Kerstendorff, Frederick Aulack, writer Enoch Baumgarten and a small committee of several noblemen and three mayors of Königsberg, as well as two representatives of smaller towns. Albrecht Truchsess stated on behalf of the Estates that they were not satisfied with the Dukely response for various reasons. There was a discussion between the Estates and the Duke's councillors, but no agreement was reached ${ }^{167}$. The Commissioners were then asked to settle the dispute. This is a moment worth emphasizing: The Commissioners are no longer imposing themselves as intermediaries, but are asked to do so. On Friday, 27 September, when, in the presence of counsellors, the Commissioners had already been acting as intermediaries, point by point, complaints from the Estates were repeatedly discussed, and measures were sought to reach a settlement and found it in part, and the Estates accepted it. On that day the Estates themselves were also in session and adopted 8,000 thalers to give to the commissioners for their efforts. Half of that sum was to be given by the cities and half by the nobility.

\footnotetext{
165 Antonius v. Borcke (1500-1575), brother of Joachim, since 1535 in the service of Duke Albrecht. In 1549 starost of Rybaki, in 1551 the starost of Pokarmin, in 1558 chief marshal, in 1575 chief steward (HB p. 238).

${ }_{166}$ Memorial, PTT, p. 800-801.

${ }^{167}$ None of the known sources give its content, which is a pity, because this material would undoubtedly be very interesting.
} 
On 28 September, the Commissioners informed the Estates that they could not come to them on that day. Why? Apparently, they did not want to engage in too long discussions that would have no effect and would have jeopardised their authority. After all, they promised to rewrite all their accusations and to give them to the Duke, to confirm and to seal them. It follows from this that this was the first edition of the later decree of 4 October, since it was envisaged that the Duke would approve and seal it.

In the next few days nothing special happened - both the diary of the Landtag and of the Commissioners informed. The only important thing was to re-establish the former burgrave, Christoph Kreytzen, in the office, which was a further step on the way to returning to the old order.

On Thursday, October 3rd, the Landtag was reconvened. Albrecht Truchsess said that voices were being spread as the majority of the population, both the nobility and the burghers, were against the harsh treatment of the imprisoned three new councillors, and only a few envious people wanted it. After these words, the Chamber was in turmoil. The Estates demanded that the Commissioners be told that this was a lie. That was what Albrecht Truchsess did on behalf of the Estates. Then the payments were debated. And so it was agreed that the alienation of goods, which took place during Skalich's rule, and the money, goods, castles, etc. that was given out at that time, should be erased. The goods in the Kreuzburg county endowed to Skalich must be erased along with thousands of thalers of annual salary and 40 Hufen of wasteland. Also the salaries of Funck, Horst, Schnell, Windeysen, Steinbach and many other Dukely servants were to be cancelled. In addition, the lands of Faustin Nimptsch should be taken away as well as the endowment of village of Bochersdorff from Loitzens ${ }^{168}$, bankers of Gdańsk. Peter Mörlein's printing house ${ }^{169}$, where Skalich printed his lampoons, was to return to the Duke. Other reductions and deletions were also to be made. To this end, a document must be prepared and published throughout the country so that those who have a legal claim against the Duke can make themselves known at the appointed time. In this way, the third period of the Landtag ends. Unfortunately, the sources are incomplete here. We do not have a clear picture of the negotiations that led to the issuance of the decree of 4 October 1566. The relentless Duke almost capitulated, handing over his favourites to the Commissioners on 14 September. At the same time, the Estates filed a complaint on 19 September not against the defendants, but against the poor

168 The Loitzens, the Szczecin bankers. The Loitzens operated in northern Germany. First, they only owned an agency in Gdańsk (see M. Wehrmann, Geschichte der Stadt Stettin, Stettin 1911, p. 215). After the death of Johann Loitzen (1558), the mayor of Szczecin, the bank was owned by the brothers Michał and Szymon, who moved the seat of the bank to Gdańsk. (Altpr. Biogr., Bd. I, p. 406/2).

169 Peter Mörlein - valet of Duke Albrecht 
order in the state, demanding the return to the former state. That complaint was the basis of the decree of 4 October, since Adolf Pawiński informed the reader that the content of that letter could be found in the material contained in the diary on 30 October $^{170}$. At the same time, a great many former dignitaries were reinstated in their former posts. After 17 September, there is a break in the judicial process, and most of the Commissioners' efforts are being made to restore order in the country.

\section{THE FOURTH PERIOD. From the issuance of the first decree until the end of the Landtag. (4 October 1566 - 2 November 1566) ${ }^{171}$}

The new period, like the others, contractually separated, was the most positive in the history of the Landtag for the Estates and commissioners, and it was a total failure for the Duke. Here is the history of this period, extracted from the diary of the Landtag and extended to include the content of decrees.

On Friday, 4 October, a consultation was held on how to deal with the burden on the country and cities. That is all what the diary says. Nothing is mentioned on that date about the decree in either the Landtag's nor the Commissioners' diary. In both on 30 October, it is mentioned about the public reading of the decree in the Landtag andits confirmation by the commissioners. It is clear from this that the decree was approved by the Duke on October 4, but has not yet been declared. The diary of the Landtag does not give anything concrete about the decree, it only mentions its existence, but it does not even give the date of its publication. However, this is where it should be quoted, because it summarised the next period of activity of the Landtag and the Commissioners. The decree of 4 October was first published in $1616^{172}$, then it was published in the $18^{\text {th }}$ century by M. Dogiel ${ }^{173}$ and in the $19^{\text {th }}$ century by A. Pawiński ${ }^{174}$ What was its content?

\section{Church matters}

The Duke will appoint two bishoprics, Sambian and Pomesanian, until Easter 1567 who are men of wisdom, merit and God-fearing, with the prior agreement and consent of the nobility. The bishop was to be elected by 16 people -8 from the nobility and 8 from the cities. These representatives are to ensure that the right choice is made. In spiritual matters, bishops are granted unlimited authority. Bish-

\footnotetext{
${ }^{170}$ Pawiński, DR, p. 93: Praetereundas has literas hic diximus, cum id, quod potissimum in iis agatur, cognosci potest ex literis pacis, jam inter status ac ducatem factae, quae recessus nominantur hocque in diario sub die 30 Octobris leguntur.

${ }^{171}$ Source material in Acta Borussica, pp. 483-523. News from other sources, as before, are provided with footnotes.

${ }_{172}$ Privlegia der Stände des Herzogtum Preussen, Brunsbergae 1616, pp. 60-62, decree text in German.

173 Codex diplomaticus Regni Poloniae et Magni Ducatus Lituaniae, Volume IV, Vilnae [1764], pp. 368/1369/2, Latin text of the decree.

${ }^{174}$ DR, pp. 140-147; German text of the decree.
} 
ops have the right to freely convene synods and diocesan assemblies, to maintain the discipline and purity of science. Bishops may convene a general synod every two to three years. They are guaranteed their due participation in the Landtag, although they do not need to participate in matters of lesser importance. They are to be punished for crimes of a church nature by a church synod. Bishops are provided with 1000 Polish zlotys per year in accordance with the original regulations. The bishops residences will remain in the same places. Church visits are to take place every year according to the current regulations. As far as the choice of priests is concerned, the Church's Ordinance of 1544 must be observed. ${ }^{175}$ The patron of the parish, liege lord (Lehnherr), finds a suitable man and presents him to the church. If the candidate has not passed the examination and has not been ordained, then he will be sent back to the bishop for this purpose, and from there, after the examination and ordination, he will return to his feudal lord. If the candidate is after the exam and ordination, then he will be presented to the church and if they accept him, then the bishop will approve him. If liege lord did not fulfil this duty, the parishioners could look for a priest themselves. Bishops are to prevent the creation of sects in the church and ensure that the places of worship are properly staffed. The Duke and the government will oversee this. As for divorces, the Consistory Court can be appealed to the Royal Court.

Within a year from the present day of St. Michael (September $29^{\text {th }}$ ) a new ecclesiastical regulation is to be drawn up, which will include the teaching according to the Augsburg Confession of 1530 . The order is to be clear and short. It is intended to indicate the discipline and ceremonies to be observed in the Church. Whoever opposes these regulations is to be removed from the office of a clergyman by bishops, and if he does not want to renounce his erroneous theses, he must even be expelled from the country in order not to ferment. The importance of these church reforms was high. Osiandrism was to be uprooted and the Protestant-Augsburg religion was to reign supreme in the Duchy. The restoration of bishops was also aimed at strengthening the Orthodox Lutheran religion in Prussia.

\section{Secular affairs}

According to the Regimentsnottel (1542), government nominations are to be granted first to indigenes before all strangers. Goods associated with the office are to be used by an official only during the term of office. These goods should not be pledged or given away by the Duke. Nor should the Duke dismiss prematurely and without reason counsellors and starosts, and if he did, he should repair it. The chamber of legal advisers should be composed of five indigenes from the nobil-

${ }^{175}$ F. T. Wojak, Ustawy kościelne w Prusach Książęcych w XVI wieku, Warszawa 1993, pp. 65-84. 
ity and three doctors of legal sciences according to their privileges. If there were no such citizens, foreigners were to employ, especially in court, to ensure that the legal side is duly respected in the life of the state. The erroneous judgments in cases concerning the Magdeburg Law property, which reached the courthouse court, should be considered in accordance with the privilege of the nobility. The office and the rent camera should accept citizens prior to foreigners. As far as taxes are concerned, the Duke should be careful not to infringe the privileges of the nobility.

The Duke shall not give his hereditary throne to any of the Dukes or masters without the prior permission of the royal majesty of Poland and the Prussian Estates, and shall not enter into any alliances or promise them without their consent. If they have taken place or are to take place in the future, they must be cancelled and declared null and void.

Unnecessary Landtags should not be convened to avoid long and useless sessions. When the Landtag is convened, proposals should be sent to all districts in order to enable them to discuss them there to allow Members of Parliament to prepare themselves for these proposals so that they can submit appropriate proposals to the Landtag.

The sums of money and goods distributed to people who are unworthy of them should be taken away. The Duke should dismiss all suspects.

As for Skalich's mandate and his printing of libel, the Duke declares that it was partly due to bad information and partly without the Duke's knowledge.

The matter of the money taken from the state caste is to be thoroughly investigated.

As far as the choice of national judges is concerned, it is to remain as it is, i.e. each district is to choose two or three persons and the Duke will choose and approve one of these persons.

Culm law and national laws should be maintained as before.

The Duke should agree that each (person) may use their goods according to own will, and put new mills and inns in place of old ones, but not nearer than a mile before the city, without special privilege.

The Duke is asked to keep his subjects under their old privileges, freedoms and customs, and the Estates will remain faithful to the Duke until his death. But if the Duke should err and not listen to the requests of his subjects, then the Estates have the right to turn to the royal majesty and the Polish Crown for help and protection from the evil that threatens them.

In 1525, the Duke declared that the blamed citizens or foreigners, whose guilt is proven, should be either punished on the spot or expelled. The Duke is therefore asked to take this into account and to punish the defendants according to the legal order and advice of the nobility. 
The decree finally states that these articles were thoroughly discussed by the Duke, the Estates and commissioners, and then unanimously adopted to be observed. The decree was signed by the Duke himself and strengthened with a majestic seal. This happened in Königsberg on October $4^{\text {th }}, 1566$. That is all about decree.

We will get back to it at the end of the article. It should only be noted here that in this way the claims of the nobility were settled to a large extent, and the Commissioners, too, performed several of the main points contained in their instructions. There were still some pretensions of towns and old counsels to legal regulations. The case of the defendants has still not been solved.

What was the further course of the Landtag according to the entries in its diary?

On October 4, 1566, the Estates returned 6,000 thalers to pay off the reiters and finally free themselves from them. Albrecht Truchsess asked that three people: Christoph Ottendorf, Christoph Hofmeister and Georg Ziegler ${ }^{176}$, who had to leave the country four years ago due to Osiandrism, could return and be recognised as honorary people, and that this should be noted in the Council Book. This was then presented to the Commissioners and it was agreed that the mayor should do it.

On 5 October, the Commissioners approved the decree of the previous day, but as we wrote before that this fact was not officially announced and that this decision was awaited until 30 October ${ }^{177}$. Meanwhile, during the sessions of the Landtag, money was sought in order to satisfy the claims of Wobeser's reiters, who took the oath that they would not "disband" until they received the total promised sum of 26,000 thalers. The Commissioners advised to expel them with the help of Polish troops. The Marshal of the Chamber of Deputies Albrecht Truchsess and the Estates were reluctant to allow the new troops to stay in the country and asked the commissioners to call on the Prussian reiters to disperse under threat of corporal punishment, confiscation of property or banishment. The foreign troops were supposed to settle for money. Finally, 6,000 thalers were given, and the rest of 13,000 thalers were to be given to the reiters for the Three Kings' Day in Gdańsk or Toruń.

On that day, the commissioners sued priest from Kreutzburg, the estate of Skalich. He was sued because he was a burgrave. The priest showed the instructions left to him by Skalich and made many people laugh. Finally, the priest was ordered to clean up the accounts and give them back to the commissioners.

Albrecht Truchsess also appeared at the Landtag and demanded to sue Paul Skalich, who had been outside the borders of the Duchy of Prussia since 1565.

${ }^{176}$ All three of them were jurors of the Old Town Court of Königsberg. They were expelled from the Duchy in 1562 for publicly speaking out against the teachings of Andreas Osiander, and rehabilitated on October 4, 1566. (J.R. Fligge, op. cit., pp. 486, 515).

177 DR, p. 148. 
On Sunday, 6 October and Monday, 7 October, a further debate was held on the issue of reiters that were planning to come to Königsberg. For this reason, defensive measures were to be taken, especially to strengthen the walls and manning the castles. Meanwhile, the news came, not quite certain, that the Wobeser had been imprisoned. The appointment of the Sambian bishopric was also consulted. The candidates were: Dr Jerzy Venediger ${ }^{178}$, Dr Joachim Mörlin ${ }^{179}$, Dr Merten Chemnitz ${ }^{180}$. The process of implementing the decree of 4 October has begun. At the end of that day, a Skalich official, a priest from Kreutzburg, brought the accounting books to the Commissioners.

On Tuesday, October $8^{\text {th }}$, the "commissioner's court" over the defendants ended. The period of almost 25 days since they were blamed and handed over to the Commissioners has not brought any clear activity on the part of the Commissioners in this matter. The Commissioners have dealt with other matters. At the time when the nobility's complaints about the functioning of the state were regulated by the decree of 4 October, Wobeser was probably detained and the reiters dispersed thanks to the mediation of the colonels: Kreytzen and Packmohr, the latter case shoutd have been dealt with, i.e. the defendants should be sentenced ${ }^{181}$. So, at the town hall of Knipawa there was a lawsuit pending. First, the state prosecutor, Matthias Bögner, demanded that the testimony of the defendants be published and that the law be applied in full, when the case had come to a criminal nature. Funck, Horst and Steinbach said that they were standing by their testimony, only Schnell asked to answer again. The state lawyer Bögner refused to do so because, once he had escaped, it was not worthwhile to be questioned by law. Finally, Royal Commissioner Jan Kostka said that since this is a criminal case, they should not be involved in the matter, and that is why they issued a verdict read out by Mikołaj Firlej, the secretary of the Commissioners ${ }^{182}$. By sentence, the defendants were handed over to a jury in Knipawa. Then Kostka approached Knipawa's judge, Dominick Perbandt ${ }^{183}$, and

${ }^{178}$ Georg Venediger (+1574), studied in Wittenberg, where he received his doctorate in theology in 1550 . In 1550-1557 he was a professor of theology at the royal university. He was opposed to Osiander's teachings and for that reason he left the principality. In 1567, he was appointed bishop of Pomesania (J.R. Fligge, op. cit., index).

179 Joachim Mörlin (1541-1571), studied in Wittenberg, from 1550 he was a preacher in the Knipawa cathedral. As an opponent of Osiander, he was banished from the country. Until 1567, he was a superintendent in Braunschweig, in 1568 became Sambian bishop, (Die Religion in Geschichte und Gegenwart, Tübingen 1960, III ed., p. 1033).

${ }^{180}$ Merten Chemnitz (1522-1586), studied in Wittenberg, then for many years he was a librarian of Duke Albrecht. Being an opponent of Osiander's teachings, he had to leave the principality. In 1567 he visited the Duchy of Prussia and took part in the restoration of Lutheran Orthodoxy there. That year he became a superintendent in Braunschweig (J.R. Fligge, op. cit., index).

${ }^{181}$ Acta Borussica, p. 485, footnote.

182 Document in Acta Borussica, pp. 488 - 490, footnote.

${ }^{183}$ Dominick Perbandt (1507 - 4 II 1602). In 1566, he was a judge, then the mayor of Knipawa. He got married in 1547 with Anna, daughter of Joachim Cniper, mayor of Knipawa, widow of councillor Andreas Krause (J. Gallandi, Königsberger Stadtgeschlechter, Altpreussische Monatsschrift, vol. 201883 p. 217). 
said: "Judge, we are giving you four defendants, with a warning to do nothing but what the law says with them. To no one according to love, nor to harm, but to do so in accordance with described laws of your country and government." When the accused were escorted, Horst was supposed to say, "An appeal to the Royal Majesty is not permitted to me, God have mercy." On that day, the Commissioners sued Lukas Gabriel ${ }^{184}$, whom Albrecht Truchsess has criminalised, for Lukas Gabriel and Albrecht Pöhlman ${ }^{185}$, Skalich's lawyer, were against Truchsess. Gabriel was supposed to say in the Old Town Church in the presence of the court councillors that he was only a alleged Truchsess. He also did so in print, compromising Truchsess's honour. Gabriel replied that he was in the service of Skalich, and all this was done on the Duke's orders, with many more important persons than him. Nor did he call Trunchsess "alleged", but the case. As for the printing of Skalich's writings, he had to help his principal. He can also prove that he and Schnell removed half of that letter. He asked to be released from Truchsess's complaint. After all, Kostka postponed the case of Lukas Gabriel to the next sitting.

In the afternoon, the Landtag discussed various matters in the Old Town Hall ${ }^{186}$. The Kanitzs spoke out, asking that the Estates be on their side, because they acted for the common good. On the next day, i.e. 9 October, a new trial against the defendants was initiated. It was the third court in a row.

On Thursday 10 October at 2 oclock in the morning, joint negotiations between the Commissioners and the Estates took place. Kostka spoke how to deal with some of their requests and complaints. As for the porch leading to the church, let it remain, because it does not seem to be particularly harmful to the city. As far as these two gates are concerned, the Duke is to find in the chancellery what it actually happened, but the lower gate should be closed. Cities showed then their privileges, from which it appears that the entire wall, until the upper gate, belongs to them and asked so it continues to protect them. At the end, Kostka called on the Estates to adopt a tax for the Duke, so that he would not remain in poverty, pointing out that this tax is to be adopted on a one-off basis. Finally, Albrecht Truchsess thanked the Commissioners for their efforts so far and asked them to stay until the end of the trial against the accused (we can presume the Commissioners have already expressed their willingness to return home).

${ }^{184}$ Lukas (Lux) Gabriel from Old Town, attorney. In the trial of Paul Skalich with Albrecht Truchsess in 1565, he was the spokesman of the former one. As a result, he differed from Albrecht Truchsess and on 8 October 1566 he was considered a highly suspicious person, but already on 12 October 1566 he acted as a spokesman for the Estates. Contemporary to him. K. Hennenberger, Erclerung der grossen preussischen Landtafel, Königsberg 1595 , p. 228, regards his death as a punishment for perverse legal proceedings. The last message about him is from 5 III 1572 (HB, p. 179, footnote 2).

${ }^{185}$ Albrecht Pöhlman - no data available

186 This discussion is not given by the Landtag's diary, and this material would certainly be interesting. 
The next almost ten days were filled with litigation against the new counsellors, and this is the subject of a separate article by $\mathrm{me}^{187}$. The Landtag, on the other hand, did not deliberate.

It was not until Saturday, 19 October at 2 oclock in the afternoon, that a joint state session with the commissioners and Duke's councillors took place in the Old Town Hall. Kostka announced that the Duke wanted to have the complaint of the cities about the castle gate and the porch reviewed by impartial judges. For this reason, the cities will have to wait for the outcome of this examination. He then asked whether the Estates wanted to help the Duke with the tax, to which the Estates did not want to give an answer until their injuries were eliminated and the new privileges were approved. This is a clear allusion to the decree of 4 October. Only the consideration of the matter of filling the bishoprics and the vocations of the expelled preachers enabled the Estates to move to the next Landtag.

Then Albrecht Truchsses complained against burgrave Kasper Nostitz ${ }^{188}$ that he was a bad and embezzling counsellor. Nostitz denied everything. A similar complaint was lodged by Melchior von Lehnsdorff ${ }^{189}$, through Heintz Follert, ${ }^{190}$ requesting that Nostitz be removed from government.

Meanwhile, on 20 October, Secretary Jan Dymitr Solikowski brought a royal letter to the Commissioners dated 16 October in Warsaw ${ }^{191}$. The content of the letter was as follows:

1. Mr Gdański (Jan Kostka) is to ensure that what the Commissioners have agreed is implemented after they leave.

2. "We order those who deserve it by law to be punished by the presence of yours."

3. The old will (first one) is to be preserved.

4. Paul Skalich should be proscribed.

5. No foreign Duke, and especially from Mecklenburg, should be allowed into the Duchy of Prussia.

6. The King announces that he will send a deputy to the new Landtag and hopes he will receive financial aid from Prussia.

\footnotetext{
187 See footnote 2 .
}

${ }^{188}$ Kasper v. Nostitz (1500 - † 22 III 1588), son of Kasper, came from Silesia. Lutheran, studied in Krakow, Vienna and Wittenberg. He came to Prussia in 1534 and in 1534-1538 was the Mayor of the castle (Hausvogt), since 1538, the camera counselor. He was an opponent of Osiander. In the period preceding the Landtag of 1566, he has not been completely involved with the new counselors. Suspected at the time of the 1566 Landtag of participating in the drafting of the will from 14 May 1566. From $13^{\text {th }}$ March to $18^{\text {th }}$ June 1566 , the chief burgrave, from $8^{\text {th }}$ July 1566 - 1578 again the camera councillor (K. Lohmeyer, HB, Einleitung; Altpreussische Biographie, v. II, z. II, pp. $474 / 2$ and $475 / 1)$.

${ }^{189}$ Melchior v. Lendorff (1534-1602), the youngest of three brothers. In the years 1573-1582 he was the starost of Bałga (HB, pp. 251-252).

${ }^{190}$ Heinz Follert, came from a noble family in Halberstadt. From 6 June 1552 to 1583 an administrator of armoury "Rüstmeister". He was well seen by new counselors (HB., pp. 253-254).

${ }^{191}$ Printed by A. Pawiński, DR, pp. 132-134, reprinted by A. Vetulani, Władztwo Polski, pp. 191-193. 
7. The annulment of the oath to margraves (of Brandenburg) can be translated into the Landtag in the Pótpoście (1567).

On 22 October, a decree was issued - the Landtag's diary does not mention it. It concerned the cities ${ }^{192}$. This decree mainly concerned economic issues, which had hitherto plagued the cities. From the political point of view, the activities of the Landtag in the decree are worth noting.

The decree announced that the Duke should consider fairly the violations of freedoms, civil rights, the removal of old counsels and the appointment of new ones, the issuing of unjust mandates, orders and court rulings, as well as the impunity of raiding criminals. The Duke should punish all those who caused it.

Since two years ago two Knipawa councillors, Jacob Quandt ${ }^{193}$ and Matthäus Reiner $^{194}$, and three Old Town councillors, Christoph Ottendorf, Christoph Hohenmeister and Georg Zengler, were illegally removed from office, they or their descendants should be heard.

Other issues that are included in the decree are to be cited:

1. All advisors and professors are exempt from civic duties, e.g. guard duty, but nobody from ordinary servants is.

2. The Duke recently banned imports from the Warmian bishopric, which are to be settled for mutual benefit by the commissioners.

3. As regards Klaipeda's trade, the Duke will want to ban trade in Klaipeda and prohibit strangers from arranging granaries there and "“taking goods out to sea”.

4. Jews do not have the right to keep goods in the granaries of Königsberg, just as it is in Gdańsk.

5. The "Jungfrauenkloster" Monastery of Young Misses is to remain a school for young girls ${ }^{195}$.

Finally, the decree states that its content was discussed in detail and unanimously adopted by the Duke and councillors of the three cities of Königsberg through the commissioners, and signed and sealed by the Duke on 22 October

\footnotetext{
${ }^{192}$ Priv. pp. 68-70 in German. Dogiel M., op. cit., pp. 369/2-371/1 in Latin; A. Pawiński, op. cit., pp. $148-153$ in German.

${ }^{193}$ Jakub Quandt - (1517-1567). In 1550, the Kniprowa juror, in the Osiander dispute was on the side of Joachim Mörlin and fell into disfavour with the Duke, but from 1556 again in the council of Knipawa (see W. Meyer, Jacob Quandt und Faustein Nimptsch zwei Königsberger Ratsherren aus der Zeit der Osiandrischen Streitigkeiten, Altpreussische Geschlechterkunde, 3 Jhrg., H. 1, Königsberg 19291929, pp. 83-89).

194 Matthäus Rainer - his son could have been Matthew Reiner ( $\dagger 1594)$, who in 1571 was the mayor of Knipawa (J. Gallandi, op. cit., p. 464).

195 The issue of liquidation of female monasteries during the Reformation and the creation of schools for girls in their place, known in Western Pomerania and Denmark, is worth a special study also for East Prussia. I have not found the right literature yet.
} 
1566. The commissioners approved it on 25 October 1566. In this way, the claims of the cities were satisfied to a certain extent.

On Wednesday, October $23^{\text {rd }}$, the townspeople of the three royal towns met in the meeting house and it was where the decree called the privilege with the Duke's signature and seal, was read to them. Then the mayors said that the decree should satisfy six townsmen, and therefore a tax for the Duke should be thought of. The citizens of Knipawa believed that there was little freedom in these new privileges and that they would soon be curtailed. Finally, the voices against the new city councillors started to rise, saying that they were appropriating public money. It has been requested to address the Commissioners in order to remove these people from office. They also demanded that the bishops' offices be filled. The Sambian bishopric should be taken over by Dr Joachim Mörlin and the Pomesanian bishopric by Dr Georg Venediger. In turn, Mgr Egidius ${ }^{196}$ should become a priest in the cathedral church. The Mayor of Knipawa, Kasper Nepfel, responded to all this by saying that he was sorry that he would not be welcomed by the assembly with gratitude, but that this time he would not go to the Commissioners. He is not against a reform of the municipal government, but he cannot admit that he has ever appropriated a public penny in his life. In the afternoon, a committee of all the towns met in the Old Town Hall and Mayor Kasper Nepfel said that the tax issue should be discussed.

Meanwhile, on Friday, 25 October, a new decree was issued ${ }^{197}$. It was a settlement between the Duke and the chief advisers. It did not contain any specific wording, it only explained how to maintain good relations between the chief advisers and the Duke and how to avoid a return to evil after the present reconciliation. Actually, the decree put the power in the hands of the chief advisers. Except for them, no one was supposed to have access to the Duke. On that day, the Commissioners approved the decree of 22 October for the cities.

So the main complaints of the Estates were dealt with by decrees. Some of them were moved to the next Landtag, but the case of the defendants has not been solved yet. So now it was approached even faster. On 25 October the trial in Knipawa was resumed. On Saturday, October $26^{\text {th }}$, a joint meeting of commissioners, Duke's councillors and Estates took place in the Old Town Hall. Albrecht Truchsses spoke in connection with the one-year tax passed for the nobility, covering excise duty (Bierpfennig) and field tax (Hubenschoss). Truchsess demanded the payment for reiters and the purchase of pledges. This tax was supposed to give $648766 \mathrm{Marks}^{198}$. Then the commissioners told the Estates that they wished that the seats of the Duke's councillors, especially the starosts, would be properly filled. Suspects should be put at a dis-

\footnotetext{
196 Egidius - no data available

${ }^{197}$ Printed only in Priv. pp. 64-66 (in pagination often mistakes).

198 AB, p. 525, footnote.
} 
tance: the burgrave Kaspar Nostitz, the builder Peter Mörlein and his son Clement, the kitchen writer. The Commissioners went on to say that they could only stay here until Tuesday and that the trial against the accused should therefore be speeded up. Then A. Truchsess asked the Commissioners to order the court to conduct the trial faster. He also asked the commissioners to ensure that the Duke did not show disgrace to any of the Estates because of what would happen to the defendants. The preacher Ottomar Eplinius ${ }^{199}$ also appeared before the Estates, who was to inform Funck that the old councillors wanted to lock the Duke in the Moscow Hall.

Finally, on that day, Horst in prison wrote a letter to Funck, in which he departed from Osiandrism ${ }^{200}$. It was undoubtedly one more manoeuvre to save one's life.

Meanwhile, the trial was coming to an end. On $28^{\text {th }}$ October the defendants were questioned for the last time and a death sentence was passed, recognising Horst, Funck and Schnell as destroyers of peace and traitors to the country. Steinbach escaped sentence because he was seriously ill (bleeding). The last act of this long process took place already at 11 o'clock in the morning on that day. Three new councillors put their heads under the executioner's axe. That was how the fate of the Duke's confidents ended miserably.

The day after the execution of the verdict, i.e. on Tuesday, 29 October, the Landtag held its final session. Albrecht Truchsses said that all burdens on the country and cities should be removed. A deputy should be sent to Poland to the Landtag to ratify the matters settled and to ask for recognition of all the freedoms, liberties and privileges of the country. This statement shows that the decrees of 1566 were not supposed to be the last demand of the Prussian Estates. Then Truchsess moved on to the Governorate case. Because the dynasty is based on "four eyes", the old Duke is sickly, and the young Duke will not be able to rule yet, so it may happen that this country will fall to the Polish Crown, which may happen by God's grace. Therefore, it is necessary to make an effort for the Polish King to ensure that in the event of the death of the old Duke, the governor is an indigene, who knows the German language, so that the country is not managed by someone else. The Duke of Mecklenburg should be requested to renounce: the Governorate, the Franconian fief, the record of 10,000 Polish zlotys and the new will. Bishoprics should be staffed. Finally, 8,000 thalers - let us add - should be given as allowances to the Commissioners in connection with their departure.

On Wednesday, October 30 afternoon, a joint meeting of commissioners, Duke's councillors and Estates took place. Commissioners handed over to the Es-

199 Eplinius Ottomar - (b. ca. 1525 - d. 2.II. 1567). The place of his studies is not known. In 1550 he appeared in the Duchy of Prussia and took the office of a Dukely preacher. He was in favour of the teachings of Osiander. (J.E. Fligge, op.cit. pp.161-165).

${ }^{200}$ AB, pp. 398-414. 
tates the decrees they had approved so far (the decree of the cities was announced on 23 October). So the decrees were already announced. It was then agreed that all donations and records should be deleted. Then Chancellor Johann Kreytzen spoke, declaring that this could not be universal and that the good name of the Duke could not be compromised. Afterwards, Jan Kostka announced the annulment of an oath taken by the Prussian state in 1563 against the Brandenburgers. In the end, however, this matter has been postponed. It is further stated that Skalich was to be proscribed $^{201}$ and his goods confiscated ${ }^{202}$. Steinbach was declared outlawed, his illness saved him from the fate of his companions ${ }^{203}$. Steinbach made a promise on November 1st that he would leave Prussia forever within 14 days and would never take revenge for what happened to him here.

At the end of the meeting, Albrecht Truchsses thanked the commissioners and asked that the Royal Majesty and Crown of Poland continue to be as gracious as ever.

On 31 October at 11:00 oclock in the morning, the commissioners left after a 69-day hard working stay in the Duchy of Prussia.

On 1 November the Landtag was deliberating without commissioners in the matter of the tax imposed, while on 2 November, on Saturday, Estates authorised "castemasters" to collect money. Then the deputies dispersed, everyone went their own way home and the momentous Landtag ended.

\section{Termination. Effects of the Landtag}

Summing up the course and effects of the Duke's of Prussia Landtag in 1566, it is necessary to stop at three issues. These are:

The trial of the new counsellors.

Decrees - results of the activities of the Landtag.

The effects of the 1566 Landtag.

The trial of the new councillors, led by the three courts, the Duke, then the Commissioners, and finally the jury made up of judges from the three cities of Königsberg, led to the death sentence. Was it fair? Opinions are different here. In the $16^{\text {th }}$ century (David Chyträeus) and in the $17^{\text {th }}$ century (Christoph Hartknoch), did not question the validity of the verdict, but rather one can sense a clear antipathy for the new counsellors, especially in Chyträus. In the $18^{\text {th }}$ century, a Prussian historian Ludwik Baczko stood up for the defenders. ${ }^{204} \mathrm{He}$ considers the verdict

${ }^{201}$ Dogiel M., op. cit., pp. 372/1-373/1 in Latin in Erleutertes Preussen, Königsberg 1726, vol. III, pp. 298-303, in German with date 28 X 1566.

202 Dogiel M., op. cit., p. 373.

${ }^{203}$ APO V/3-6, pp. 106-107, PTT, pp. 819-820.

${ }^{204}$ L. Baczko, Geschichte Preussens, Königsberg 1795, vol. IV, p. 313, writes: “ So ward der Justizmord vollbracht. Die drei unglücklichen Staatsopfer erhielten... ein gemeinschaftliches Grab.” 
a legal murder, emphasizing the inadequacy of the court. Leopold Ranke took over these views. ${ }^{205}$ Max Toeppen, ${ }^{206}$ the best expert on Dukely Prussia state cases, believed that the defendants were convicted without a proper trial. J.G. Droysen ${ }^{207}$, in his description of the Landtag of 1566, based on him, omitted the conviction of the new advisers. It is worth noting the views of G.A.H. Stenzel ${ }^{208}$, who believes that in this case the Duke's councillors were not without guilt, but that the complainant, the Prussian Estates, also bore some blame.

Adolf Pawiński dealt with the trial in more detail ${ }^{209}$. He discussed Baczko's views, believing that the judgment against the new counsellors was correct, since they were guilty of high treason. Then L. Poblocki defended the new advisers ${ }^{210}$, stating that so far the Prussian Estates from the years 1566-68 were viewed too optimistically. Later this problem was not raised in literature (Karl Lohmeyer, Bruno Schumacher, Adam Vetulani, Kazimierz Piwarski). Recently K.D. Staemmler ${ }^{211}$ wrote that the Duke and judges are to blame for the sentence, not the Polish commissioners, because they stayed away from the sentence, all the more so because there was nothing to win for the Crown.

After a brief presentation of the views in the literature, one should present one's own view. First of all, however, it should be pointed out that we do not know all the sources and, above all, the files of the judicial process ${ }^{212}$. Therefore, we can only base our opinion on a bill of indictment ${ }^{213}$, testimonies ${ }^{214}$ and diaries: of the Commissioners ${ }^{215}$ and the Landtag ${ }^{216}$.

As for the inappropriateness of the court, Baczko's reservations are undoubtedly correct, as the accused Horst had already pointed out before him that a court composed of city jurors also represented the plaintiff and asked for an impartial court at that time. A. Pawiński asked where to look for those impartial judges. It

${ }^{205}$ L. Ranke, Zwölf Bücher Preussische Geschichte, Sämmtliche Werke, vol. 25, 26, p. 171, Leipzig 1874.

${ }^{206}$ M.Toeppen, Zur Geschichte der ständischen Verhältnisse in Preussen, Historisches Taschenbuch, ed. F. v. Raumer, Neue Folge, r. 8, Leipzig 1847, p. 481, writes: “...Funck, Horst und Schnell wurden ohne ordentlichen Process verurteilt und (...) hingerichtet."

207 J.G. Droysen, Geschichte der Preussischen Politik, ed. II, vol. II, part 2. Leipzig 1870, pp. 306-307, p. 470, relevant footnote.

${ }^{208}$ G.A.H. Stenzel, Geschichte der preussisches Staats, vol. I, in: Geschichte der europäischen Staaten, hrsg. von A.H.L. Heeren and F. A. Ukert, Hamburg 1830, p. 340.

${ }^{209}$ A. Pawiński, Sprawy Prus Książęcych za Zygmunta Augusta, Źródła dziejowe, vol. VII. Warszawa 1879, pp. XCIX-CII.

${ }^{210}$ L. Poblocki, Die Zeit der grössten Abhängigkeit des Herzogthums Preussen von Polen in den Jahren $1566-$ 1568, Zeitschrift für Preussische Geschichte und Landeskunde, Bd. 12, Berlin 1883, p. 253.

${ }^{211}$ K.D Staemmler, Preussen und Livland in ihrem Verhältniss zur Krone Polen 1561 bis 1586, Marburg a.d. Lahn 1953, p. 29.

${ }^{212}$ Referred to by AB, p. 218, footnote.

213 APO V/3-6 and AB.

${ }^{214}$ APO V/3-6 and Memorial, PTT.

215 DR.

216 AB. 
seems that they could have been recruited from the so-called "middle party", i.e. the chief advisers, dismissed by Duke Albrecht in spring, but for the sake of justice, we must admit that they were not eager to do so, believing that this is a throat issue.

We should also consider whether the sentence was due to the guilt of the accused or whether it was a form of expression of the state party's victory over the Duke's party. The testimonies of the defendants were unambiguously political in nature, so if the Duke's party won, would guarantee, at least, immunity. On the other hand, there have been incidents of abuse of power and bribery. The former included the removal of old advisors, governorship, change of will and recruiting of the mercenaries; the latter money received from Mecklenburgers, Baden's margrave, Colonel Wobeser and Loitzen bankers, as well as extortion of money and goods from the Duke.

In principle, the state coup was half-trumpeted, i.e. the uncomfortable old councillors were removed, the "Law on the Government" was overthrown (Regimentsnottel) of 1542 by the establishment of a new will which provided for the governorhood of Mecklenburg, and not a state regency, as this law provided in the event of the minor status of the ruler, composed of four superintendents, four chief starosts and three mayors of Königsberg. The power was solely in the hands of the Duke's party, i.e. the new counsellors. The aim was to maintain this state of affairs, but the lack of money forced the court party to convene a Landtag, where the Estates were to be forced by the presence of reiter mercenaries to pass a tax. That was the essence of the planned coup détat of the Duke's party. Then absolutism would have prevailed in the Duchy of Prussia, based on court camarilla. As far as the Duke himself was concerned, there is nothing to say ${ }^{217}$. Apart from these plans, there were other, broader, but adventurous and unrealistic plans, represented by Mecklenburger, to form an anti-Polish alliance. Wobeser's reiters were also claimed by Mecklenburger, but to use them in Prussia to force the Estates to pay taxes was the work of Horst and Schnell.

Of the four defendants, only Schnell was really reckless. Contrary to the literature to date, it must be admitted that all of them were educated people and, apart from their inclinations to abuse money, one could only make one accusation: they could not carry out plans according to which the Duchy of Prussia would become an absolutist duchy. It is true that they were opposed by a well-established state party that saw the policy of the new councillors as an assault on its own privileges. So who should I say was right? What was better for the country, the victory of the state party or the Dukely party? Certainly, the aim was to bring peace to the country and undoubtedly at that time it could only be provided by the state party as stronger.

${ }^{217}$ M. Töppen, Zur Geschichte der ständische Verhältnisse, p. 476. 
Therefore, in the judgment, I see no evidence of betrayal of the country by the new counsellors, but of a different concept of a state in which they would undoubtedly have a great deal of influence. That is why the judgment, ethically speaking, was not fair, but was an expression of a political victory of the Estates. The new councillors were not criminals, they caused a turmoil in a country that could have led to civil war, but all this was a struggle to see whether Prussia would be an absolute principality or a "noble republic". The victory was on the state side, so the opponents were executed.

It is all the more important to stress that the Estates did not agree to the transfer of the accused to Poland by the Commissioners. They wanted to declare their strength in a verdict on the spot. The victory of the Estates was expressed not only in the physical destruction of enemies, but above all in the new privileges - decrees, the content of which is given above.

The decrees, resolutions of the Landtag signed and sealed by Duke Albrecht and confirmed by royal commissioners ensured the victory of the nobility in this conflict and strongly brought the Duchy of Prussia closer to a state with a similar system to Poland, i.e. a noble democracy with a limited power of the monarch.

First of all, the former privileges of the nobility were confirmed, the most important of them being the Constitution "The Law on Government" of 1542. Decrees not only restored the former state before the attempt of a complete revolution in the state by the group of Skalich-Horst, but also went further. As far as church matters are concerned, the bishops were restored. The demand for the appointment of bishops results from the fact that the office of the presidents of bishoprics was introduced under Osiander (1550 and 1551). Therefore, it did not enjoy a good reputation among the Estates. Besides, it did not provide a dominant position in the church, which was given to the bishop's office. Thus, there was a lack of discipline in the church, and this further led to sectarianism, ecclesiastical and intra-state disparities. The Estates had secured their influence over the election of the bishop, since a commission of 8 representatives of the nobility and 8 representatives of the cities had been set up to elect him. The only thing left for the Duke was the bishop's approval. The bishops were provided with all the old rights. According to the Estates, their thought was that the former Osiander church order of 1558 should be changed over the course of the year to a new order based on the Augsburg Confession of 1530. They also reserved the right not to tolerate sects that break up the church.

In secular matters, the Estates guaranteed themselves that the offices would be occupied by citizens prior to foreigners. Further, the Duke should not remove advisors and starosts without any special reason. The Chamber of Counsels was established for 8 persons, including 5 indigenous nobles and 3 doctors of law, if they 
do not have their own, they can be foreigners ${ }^{218}$. In all the offices, the citizens were to have priority over the foreigners. Each district was to propose 2-3 judges and the Duke elects and approves one of them.

Finally, after securing its influence over the offices, the nobility guaranteed itself the right to appeal to the King and the Polish Crown for help if the Duke did not keep them in the privileges they had enjoyed so far.

The Duke was also limited to such an extent that he had no right to form any alliances without the consent of the Prussian Estates and the Polish Crown. Any alliances formed without this consent were not valid. Plus the decree of 25 October 1566 - the agreement between the Duke and the government councillors provided that only these councillors would have access to the Duke. The Duke was thus separated from other influences ${ }^{219}$. The Duke, sick and broken, did not play any role anymore, the power was intercepted by the chief advisers. Despite the fact that a small group of people captured the main power, the overall victory belonged to the Estates and, above all, to the nobility, (the townspeople received only some economic concessions in the decree of 22 October 1566) and therefore, although in fact the Duchy of Prussia was still a principality, in reality it became close to the system of "noble republic"220. The nobility was guaranteed all the offices in the country. The influence of the cities was further reduced by the article of the decree of 4 October 1566, which spoke of the primacy of the local nobility over all offices. Previously, the "Order of the Government" (Regimentsnottel) guaranteed priority only for certain offices ${ }^{221}$.

Yet the Estates could not fully use their victory over the Duke, because they did not ask for the Landtag to be convened regularly. The Estates, and above all the nobility, did not have a clear programme of reconstruction of the Duchy's system $^{222}$. They did not take into account the fact that councillors could turn their backs on state policy, and did not guarantee their control over them. Georg Frederick, who used it later on and did not convene the Landtag, ruled without the Estates.

Despite these reservations, it should be strongly emphasized that the coup of 1566, even called the revolution (Kurt Breysig), was a victory of the concept of a noble republic over the absolute principality. This happened only and exclusively thanks to the support of the Polish Crown, through the sending of commissioners. The nobility, slowly gaining new privileges, came to the conclusion that in 1566 it

${ }^{218}$ K.D. Staemmler, op. cit., p. 30, made a mistake and attributed this composition not to the Chamber of Counsels, but to the Royal Court.

${ }_{219}$ Only C. Wichert curiously extracted the main content of this complex recession, op. cit., pp. 437-438.

${ }^{220}$ B. Schumacher, Geschichte Ost und Westpreussen, Würzburg 1958, p. 157.

${ }^{221}$ A. Vetulani, Polskie wplywy polityczne w Prusiech Książęcych, Gdynia 1939, p. 41.

222 Ibidem, p. 42. 
changed the political character of the principality. From this moment the power of the Estates begins, broken many times, until the seventeenth century, when it was ended completely by Frederick William ${ }^{223}$.

On the other hand, the Polish sovereignty over the Duchy of Prussia was very strong. This is explained by the effective activity of the Polish Commissioners, who are told by Staemmler that, thanks to their interference, the civil war that threatened in 1566 was averted ${ }^{224}$. The Polish leadership was also visible in the following years, 1567 and 1568, when the commissioners again stayed in the Duchy of Prussia ${ }^{225}$. This time they were again mediators between the Estates and the Duke, rather the chief council. They smothered quarrels and brought peace to the country. They restored the first will, removed the young Duke's chief steward, Jacob Schwerin, and in his place appointed Kasper Lehndorff, who according to the royal instruction was to teach Albrecht Frederick the Polish language, which the young Duke mastered. The Polish sovereignty over the Duke was expressed through the control of Albrecht's foreign policy, especially his relations with the Reich, and the annulment of the resignation of the Franconian fief to Mecklenburg 226 . However, the commissioners did not succeed in restoring Duke's donations to the Prussian treasury, the Prussian Estates did not approve the royal treasury allowance, and finally, the term "indigene", a native was not extended to "possesionatus", the owner of the estate. The Prussian Estates rightly feared that Poles with property in the Duchy of Prussia would be able to take over offices there ${ }^{227}$. By implementing the decree of 4 October 1566, in 1567 bishoprics were manned: the Sambian was taken by Joachim Mörlin, while the Pomesanian by Georg Venediger; a new Lutheran ecclesiastical ordinance was also issued, entitled "Repetitio corporis doctrinae ecclesiasticae"228.

On March 20, 1568, Albrecht died after surviving 78 years. The commissioners who came to Königsberg opened a last will and testament in which the young Duke's guardian was the Polish King Sigismund Augustus. Mecklenburg's claims have been dismissed ${ }^{229}$. Other things have been done, too. As a result, "new titles came to Poland's former supreme rights: for once the only time a fiefdom land should give a financial allowance to its master and indirect ruler, it had moreover

${ }^{223}$ Ibidem, p. 50.

${ }^{224}$ K.D. Staemmler, op. cit., p. 32.

${ }^{225}$ Commissioners' Diary for the years 1567 and 1568 and a list of their activities: A. Pawiński, DR. Dzieje ostatnich sejmów za życia Albrechta, M. Töppen, Die preussischen Landtage zunächst vor und nach dem Tode des Herzogs Albrecht, Programm des Königlichen Progymnasiums zu Hohenstein in Preussen, Hohenstein 1855 and E.K. B. Kleinertz, op,cit.

${ }^{226}$ Pawiński, DR, p. CXXIX.

${ }^{227}$ Ibidem, DR., p. CXVII.

228 C.A.Hase, op. cit., pp. 383 and 385-386.

229 F.W. Schirrmacher., op. cit., p. 675. 
to belong with entire army to the whole Crown - the governor's council during the underage of the Duke took such an oath to the Polish King" ${ }^{230}$. The oath taken by the Estates to the Brandenburgers was finally revoked ${ }^{231}$.

It seemed that the expiry of the Prussian Hohenzollern line would soon result in the incorporation of the Duchy of Prussia into Poland. That did not happen, but it goes beyond the content of this article. However, Polish historians (e.g. Kazimierz Piwarski ${ }^{232}$ ) point to the fact that not all possibilities have been exploited because the Polish governor was not established. In the summer of 1566, Kanitz proposed to the King that he appoint Jan Kostka as governor. These possibilities existed - in my opinion - and were to be exploited, but only in 1566 at the beginning of the Landtag, when the Estates forced by the oppression of the court party would have agreed to any form of assistance. However, this would require the King to have a clear anti-ducal policy, which would deplete the Duke's prerogatives too much, while the Commissioners acted as intermediaries. Besides, Albrecht was the King's cousin.

Finally, it must be admitted that the Landtag of 1566 was a victory for the Estates and changed the political character of the Duchy, and expanded the sovereignty of Poland over the Duchy of Prussia as never witnessed before ${ }^{233}$.

\section{Janusz Małłek, Dzieje sejmu Prus Książęcych 1566 roku}

Streszczenie

Artykuł poświęcony jest dziejom sejmu Prus Książęcych z roku 1566, który stał się przełomowym w relacjach miedzy panującym ks. Albrechtem a stanami pruskimi oraz między lennem pruskim a państwem zwierzchnim Polską. Jego rezultatem było udaremnienie absolutystycznego zamachu stanu tzw. nowych radców książęcych i przejęcie na okres najbliższego dziesięciolecia de facto władzy w Księstwie Pruskim przez stany pruskie, a dokładniej przez oligarchię pruską. Była też szansa, choć niewykorzystana, wprowadzenia polskiego namiestnika, który rządziłby księstwem z powodu niedołężności starego księcia Albrechta (1490-1568) i zbyt młodego do sprawowania tutaj władzy, bo 13-letniego księcia Albrechta Fryderyka. Jednak nadzór Polski nad księstwem został powiększony, choć w mniejszym zakresie. Zagwarantowano szlachcie pruskiej prawo zwracania się do króla polskiego i Korony Polskiej o pomoc w wypadku gdyby książę pruski naruszał jej przywileje. Poza tym władca ten, nie miał prawa zawiązywać żadnych sojuszów bez zgody Korony Polskiej i stanów pruskich.

Tłumaczenie Janusz Małłek

${ }^{230}$ Pawiński, DR, pp. CLIII - CLIV.

231 Ibidem, p. CLVII.

${ }^{232}$ K. Piwarski, Dzieje Prus Wschodnich w czasach nowoczesnych, Gdańsk 1946, p. 42.

233 The issue of how far the Duchy of Prussia approached the system of the "republic" or noble democracy is difficult, requires a thorough, comparative study. 
Janusz Małke, Die Geschichte des Landtag vom Herzogtum Preußen im Jahre 1566

Zusammenfassung

Der Artikel widmet sich der Geschichte des preußischen Parlaments von 1566, die zu einem Durchbruch in den Beziehungen zwischen dem amtierenden Fürsten Albrecht, den preußischen Ständen und zwischen dem preußischen Lehen und dem Oberstaat Polen wurde. Das Ergebnis war die Verhinderung des absolutistischen Staatsstreichs von so genannten neuen fürstlichen Ratgebern und die Übernahme der De-facto-Macht im preußischen Herzogtum für das nächste Jahrzehnt durch die preußischen Ständen und insbesondere durch die preußische Oligarchie. Es bestand auch die, jedoch ungenutzte, Möglichkeit, einen polnischen Gouverneur einzuführen, der das Fürstentum aufgrund der Schwäche des alten Fürsten Albrecht (1490-1568) und des zu jungen 13-jährigen Prinzen Albrecht Fredrick regieren würde.

Die polnische Aufsicht über das Fürstentum wurde jedoch verstärkt, wenn auch in geringerem Maße. Dem preußischen Adel wurde das Recht zugesichert, den polnischen König und die polnische Krone um Hilfe zu bitten, falls der preußische Fürst seine Privilegien verletzte. Darüber hinaus hatte dieser Herrscher ohne Zustimmung der polnischen Krone und der preußischen Ständen kein Recht, Bündnisse zu schließen.

Übersetzt von Tomasz Wyżlic

Prof. dr hab. Janusz Małłek

Faculty of History

Nicolaus Copernicus University in Torun

jm@umk.pl

\section{Archival sources}

Archiwum Główne Akt Dawnych w Warszawie (AGAD)

Central Archives of Historical Records in Warsaw

- Crown Metric 102 (diary of commissioners).

Archiwum Państwowe w Olsztynie (APO)

State Archive in Olsztyn

- Preussische Landtagshandlungen, Sygn. V/3-6.

\section{Primary sources}

Codex diplomaticus

1764 Codex diplomaticus Regni Poloniae et Magni Ducatus Lituaniae, Volume IV, Vilnae.

DR

1879 De rebus ac statu Ducatus Prussiae tempore Alberti senioris..., ed. A. Pawiński, Warszawa.

Geschichtsquellen

1907 Geschichtsquellen des burg-und schlosgesessenen Geschlechts von Borcke, ed. by G. von Selle, vol. III, part I, Berlin.

$\mathrm{HB}$

1893 Kaspars von Nostitz Haushaltungsbuch des Furstenthumbs Preussen, ed. by K. Lohmeyer, Leipzig.

Hartknoch Christoph

1686 Preussische Kirchen-Historia, Frankfurt-Danzig. 
Hennenberger Kaspar

1595 Erclerung der grossen preussischen Landtafel, Königsberg.

Historie von Funck

1732 Historie von Funck, Schnell, Horst und Steinbach, ex actis publicis mstcis - Acta Borussica, vol. III, Leipzig.

Memorial, PTT

1728-1730 Memorial was sich von der Königlichen Kommisarien Ankunft zugetragen, Preussische Todes Tempel, ed. Schultz and Lilienthal, p. 1.

Privlegia

1616 Privlegia der Stände des Herzogtum Preussen, Brunsbergae.

Urkundenbuch zur Reformationsgeschichte

1890 Urkundenbuch zur Reformationsgeschichte des Herzogtums Preussens, vol. II, ed. by P. Tschackert, Leipzig.

Vetulani Adam (ed.)

1953 Władztwo Polski w Prusiech Zakonnych i Książęcych (1454-1657). Wybór źródeł, Wrocław.

\section{Secondary sources}

Altpr. Biogr.

1941 Altpreussische Biographie, hrsg. Ch. Krollmann, K. Fortrauer, F. Gause, vol. I, Königsberg.

1969 Altpreussische Biographie, hrsg. Ch. Krollmann, K. Fortrauer, F. Gause, vol. II, Marburg.

Baczko Ludwig

1795 Geschichte Preussens, vol. IV, Königsberg.

Bodniak Stanisław

1937 Polska a Prusy Książęce na schyłku rządów Albrechta, Rocznik Gdański, vol. IX-X.

Boniecki Adam

1907 Herbarz Polski, vol. XI, Warszawa.

Bues Almut, Kąkolewski Igor

1999 Die Testamente Herzog Albrechts von Preussen aus den sechziger Jahren des 16. Jahrhunderts, Wiesbaden.

Carsten Edward

1937 Geschichte der Hansestadt Elbing, Elbing.

Czapliński Władysław

1982 Dzieje Danii nowożytnej 1500-1975, Warszawa.

Die Religion und Gegenwart

1957 Die Religion in Geschichte und Gegenwart, vol. III, ed. K. Gallig, Tübingen

1960 Die Religion in Geschichte und Gegenwart, vol. IV, ed. F. Schiele, Tübingen.

Droysen Johann Gustav

1870 Geschichte der Preussischen Politik, ed. II, vol. II, part 2, Leipzig.

Dworzaczek Włodzimierz

1959 Genealogia, Warszawa.

Flanss Reinhard von

1881 Die von der Gabelentz in Preussen, Zeitschrift d. hist. Verein für Marienwerder, H. 5, pp. 157-174. 
Fligge Jörg Rainer

1972 Herzog Albrecht von Preussen und der Osiandismus 1522-1568, Bonn.

Gallandi Johannes

1883 Königsberger Stadtgeschlechter, Altpreussischer Monatschrift, vol. 20, pp. 1-52, 193-232, 451-478, 567643

1961 Königsberger Stadtgeschlechter, Hamburg (second edition).

Gebser August Rudolf, Hagen Ernst August

1835 Geschichte der Domkirche zu Königsberg, Königsberg.

Gelmma Tadeusz

1959 Piotr Kostka. Lata młodzieńcze i działalność polityczna. 1532-1595, Toruń, Roczniki Towarzystwa Naukowego $w$ Toruniu, vol. 61 (1956).

Hase Karl Alfred

1979 Herzog Albrecht von Preussen und sein Prediger, Leipzig.

Kętrzyński Wojciech

1882 Oludności polskiej w Prusiech niegdyś krzyżackich, Lwów.

Kleinertz Everhard Karl Bernhard

1971 Die Politik der Lanstände im Herzogtum Preussen 1562-1568, Bonn.

Kleiser Georg Joseph

1992 Der Wappenmaler Johann Hennenberger und seine Grundlagenden Genealogischen Arbeiten des 16. Jahrh. zur Erstellung Preussischer Stammtafeln bzw. Adelsbriefe, Toronto.

Krabbel Gerta

1916 Paul Skalich ein Lebensbild aus den 16. Jahrhundert, Münster.

Krasiński Walerian

1906 Zarys historii powstania i upadku reformacji w Polsce, vol. II/2, Warszawa.

1948 Zarys dziejów powstania i upadku reformacji w Polsce, vol. VII/1, Kraków.

Małłek Janusz

1961 Geneza sejmu 1566 r. w Prusach Książęcych, Komunikaty Mazursko-Warmińskie, nr. 4(74), pp. 497-527.

1963 Proces kryminalny nowych radców w Knipawie-Królewcu (9.X-28. X.1566 r.), Komunikaty Mazursko-Warmińskie, nr 2(80), pp. 181-232.

2016 Od Prus do Mazur. Szkice z dziejów Prus, Pomorza, Warmii i Mazur, Dąbrówno.

Meyer William

1929 Jacob Quandt und Faustein Nimptsch zwei Königsberger Ratsherren aus der Zeit der Osiandrischen Streitigkeiten, Altpreussische Geschlechtenkunde, 3 Jhrg., H. 1, pp. 83-89

Nehring Władysław Ewaryst

1860 O życiu i pismach Jana Dymitra Solikowskiego, Poznań.

Neue Deutsche Biographie

1985 Neue Deutsche Biographie, vol.14, ed. by H. Körner, et alii, Berlin.

Niesiecki Kasper

1841 Herbarz Polski, vol. VIII, Leipzig.

Orgelbrand Samuel

1902 Universal Encyclopedia, Volume XIII, Warszawa. 
Pawiński Adolf

1879 Sprawy Prus Książęcych za Zygmunta Augusta, Źródła dziejowe, vol. VII. Warszawa.

Piwarski Kazimierz

1946 Dzieje Prus Wschodnich w czasach nowoczesnych, Gdańsk.

Poblocki Leon von

1883 Die Zeit der grössten Abhängigkeit des Herzogthums Preussen von Polen in den Jahren 1566-1568, Zeitschri$\mathrm{ft}$ für Preussische Geschichte und Landeskunde, Bd. 12pp. 245-270.

Polski Słownik Biograficzny

1848 Polski Słownik Biograficzny, vol. VII/1, Kraków.

1962-1964 Polski Słownik Biograficzny, vol. X, Wrocław.

Quassowski

1987 Die Kartei Quassowski, Buchstabe G, ed. by H. Nolde, E. Mertsch, Hamburg.

1989 Die Kartei Quassowski, Buchstabe Sa-Sd, ed. by G. Boretius, Hamburg.

\section{Ranke Leopold}

1874 Zwölf Bücher Preussische Geschichte, Sämmtliche Werke, vol. 25, 26, Leipzig.

Real-Encyklopädie

1979 Real-Encyklopädie für Protestant Theology and Kirche, ed. J.J. Herzog and G.L. Plitt, vol. 4, Leipzig.

Schirrmacher Friedrich Wilhelm

1885 Johann Albrecht von Mecklenburg, vol. I-II, Wismar.

Schumacher Bruno

1958 Geschichte Ost und Westpreussen, Würzburg.

Seebas Gottfried

1967 Der reformatorische Werk des Andreas Osiander, Nürnberg.

Siebmacher Johann

1874 Grosses und allgemeines Wappenbuch, Nürnberg.

Staemmler Klaus Dietrich

1953 Preussen und Livland in ihrem Verhältniss zur Krone Polen 1561 bis 1586, Marburg a.d. Lahn.

Stenzel Gustav Adolf Harald

1830 Geschichte der preussisches Staats, vol. I, in: Geschichte der europäischen Staaten, hrsg. von A.H.L. Heeren and F. A. Ukert, Hamburg.

Stupperich Martin

1973 Osiander in Preussen:1549-1552, Berlin.

Thielen Peter Gerrit

1953 Die Kultur am Hofe Herzog Albrechts (1525-1568), Göttingen.

Toeppen Max

1847 Zur Geschichte der ständischen Verhältnisse in Preussen, Historisches Taschenbuch, Leipzig.

1855 Die preussischen Landtage zunächst vor und nach dem Tode des Herzogs Albrecht, Programm des Königlichen Progymnasiums zu Hohenstein in Preußen, Hohenstein.

Vetulani Adam

1939 Polskie wpływy polityczne w Prusiech Książęcych, Gdynia. 
Voigt Johannes

1848 Paul Skalich, der falsche Markgraf von Veona, Berliner Kalender für 1848, 22 Jhrg., p. 49.

Wehrmann Martin

1911 Geschichte der Stadt Stettin, Stettin.

Wojak Tadeusz

1993 Ustawy kościelne w Prusach Książęcych w XVI wieku, Warszawa.

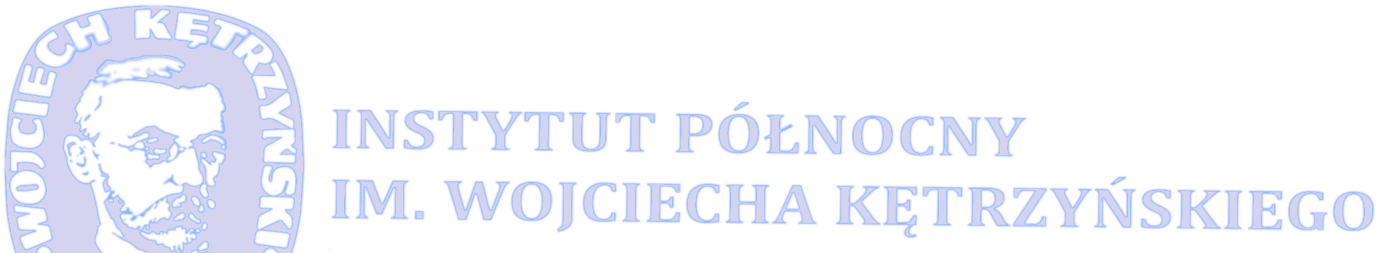

